2001

\title{
Rape and Force: The Forgotten Mens Rea
}

Kit Kinports

Penn State Law

Follow this and additional works at: http:// elibrary.law.psu.edu/fac_works

Part of the Criminal Law Commons

\section{Recommended Citation}

Kit Kinports, Rape and Force: The Forgotten Mens Rea, 4 Buff. Crim. L. Rev. 755 (2001).

This Article is brought to you for free and open access by the Faculty Works at Penn State Law eLibrary. It has been accepted for inclusion in Journal Articles by an authorized administrator of Penn State Law eLibrary. For more information, please contact ram6023@psu.edu. 


\title{
Rape and Force: The Forgotten Mens Rea
}

\author{
Kit Kinports*
}

\section{INTRODUCTION}

The crime of rape has traditionally been defined to require proof of both force on the part of the defendant and lack of consent on the part of the victim. In the words of Blackstone, rape is "carnal knowledge of a woman forcibly and against her will." This traditional "conjunction of force and nonconsent"2 has recently been subject to a good deal of criticism. While some commentators advocate that the law of rape focus exclusively on the presence of force, ${ }^{3}$

* Professor, University of Illinois College of Law. I am greatly indebted to Nicole d'Arcambal for her valuable research assistance in connection with this article and to Marcia Baron for her helpful comments on an earlier draft.

1. 4 William Blackstone, Commentaries on the Laws of England $* 210$. For a description of earlier English common law definitions of rape, which defined the crime solely in terms of nonconsent, see infra note 155 .

2. Donald A. Dripps, Beyond Rape: An Essay on the Difference Between the Presence of Force and the Absence of Consent, 92 Colum. L. Rev. 1780, 1792 (1992).

3. See, e.g., Model Penal Code $\$ 213.1 \mathrm{cmt}$. at 303,280 (Official Draft and Revised Comments 1980) (criticizing courts for placing "disproportionate emphasis upon objective manifestations of non-consent" by the woman and advocating instead a focus on "objective manifestations of aggression" by the man); Susan Brownmiller, Against Our Will: Men, Women and Rape 385 (1975) (attributing the law's "belief that force ... is not conclusive in and of itself" and its interest in "the victim's behavior during the offending act" to a desire "to protect male interests") (emphasis omitted); Catharine A. MacKinnon, Toward a Feminist Theory of the State 245 (1989) (arguing that "Mlack of consent is redundant and should not be a separate element of the crime"; instead, "[r]ape should be defined as sex by compulsion, of which physical force is one form"); Stephen J. Schulhofer, Unwanted Sex: The Culture of Intimidation and the Failure of Law 31-32 (1998) (observing that "nearly all the feminist reformers of the 1970s concluded that the best course was to eliminate from the statutes all references to the victim's consent and to focus instead on the conduct of the assailant," thereby "draw[ing] attention away from what the victim might have done and to make certain types of coercive conduct criminal in themselves"); Note, Focusing on the Offender's Forceful Conduct: A Proposal for the Redefinition of Rape Laws, 56 Geo. Wash. L. Rev. 399, 401 (1988) (taking the position that the criminal law should "shift the focus from the victim's nonconsent to the offender's forceful or violent conduct"). 
others believe that emphasis is more properly placed on the absence of consent. ${ }^{4}$ Although they ultimately come to different conclusions, these commentators agree with the fundamental premise that requiring proof of both force and lack of consent is "arbitrary," "indefensible," and "redundant," and makes the criminal law "underinclusive in ... protecting [women] against harm."

These views have made little headway. A handful of state legislatures have made nonconsensual, nonforcible intercourse a lesser offense than rape, ${ }^{9}$ and the New Jersey Supreme Court held in State ex rel. M.T.S. that the statutory requirement of "physical force or coercion" could be satisfied by proof of "nonconsensual penetration

4. See, e.g., Susan Estrich, Real Rape 63 (1987) (noting that "the problem with 'force' as a standard is ... that the focus remains on the victim," and thus "the conclusion that no force is present emerges not as a judgment that the man acted reasonably, but as a judgment that the woman victim did not"); Schulhofer, supra note 3 , at 11, 32-33 (observing that "[t]he criminal law's continuing fixation on force means that... sexual autonomy-the right to self-determination in matters of sexual life-is not directly guaranteed" and describing a few rape statutes that make "nonconsent the central element of the offense"); John H. Bogart, Commodification and Phenomenology: Evading Consent in Theory Regarding Rape, 2 Legal Theory 253, 258 (1996) (endorsing a "consent-based theory of rape"); Lynne Henderson, Rape and Responsibility, 11 Law \& Phil. 127, 158 (1992) (arguing that 'force' should not be a necessary requirement to transform heterosexual intercourse into rape"). Cf. Lucinda Vandervort, Mistake of Law and Sexual Assault: Consent and Mens Rea, 2 Can. J. Women \& L. 233, 303 (1987-88) (noting that the Canadian Parliament revised its sexual assault statute so as to define the crime in terms of nonconsent rather than force).

5. Dripps, supra note 2, at 1792.

6. Robin West, A Comment on Consent, Sex, and Rape, 2 Legal Theory 233, 233 (1996).

7. MacKinnon, supra note 3 , at 172.

8. Joan McGregor, Why When She Says No She Doesn't Mean Maybe and Doesn't Mean Yes: A Critical Reconstruction of Consent, Sex, and the Law, 2 Legal Theory 175, 181 (1996) (advocating that either the use of force or the failure to obtain affirmative consent should suffice for criminal liability).

9. For a list of such statutes, see infra note 29. But cf. Schulhofer, supra note 3 , at 71 (observing that while such statutes "fill] an important part of the gap [and] appear[ to eliminate the problem entirely,... the conundrums of the force requirement are not so easily avoided"). See, e.g., Commonwealth v. Prince, 719 A.2d 1086, 1089 (Pa. Super. Ct. 1998) (upholding a conviction under such a statute, and complimenting the jury's "apparent thoughtfulness" in reaching its verdict, even though the jury acquitted the defendant of rape on evidence that suggested the presence of force as well as absence of consent). 
involving no more force than necessary to accomplish that result. ${ }^{10}$ But the overwhelming majority of jurisdictions in this country continue to require proof of both force and lack of consent to support a rape conviction. ${ }^{11}$

A parallel debate has surrounded the mens rea requirements that apply in rape cases. Although the traditional definition of rape was silent on the question of mens rea, the issue came to the fore in the House of Lords' 1975 ruling in Director of Public Prosecutions v. Morgan. ${ }^{12}$ By a four-to-three margin, the Lords held that a rape conviction could not stand if the defendant "in fact believed that the woman consented, [even] if such belief was not based on reasonable grounds." ${ }^{13}$ The House of Lords' decision generated tremendous controversy, with critics arguing that a "man who has the inherent capacity to act reasonably but fails to has, through that failure, made a blameworthy choice for which he can justly be punished."14

10. 609 A.2d 1266, 1267 (N.J. 1992). Some commentators have criticized the New Jersey Supreme Court for "act[ing] as a super-legislature" and "effectively redraft[ingl the statute." Joshua Dressler, Where We Have Been, and Where We Might Be Going. Some Cautionary Reflections on Rape Law Reform, 46 Clev. St. L. Rev. 409, 422 (1998); see also Schulhofer, supra note 3, at 96 (same). Moreover, the approach taken in M.T.S. has been expressly rejected by a number of other courts. See, e.g., Gibbins v. State, 495 S.E.2d 46, 48 (Ga. Ct. App. 1997) (observing that "[i]n the ordinary case the [required] force... is not the force inherent in the act of penetration but is the force used to overcome the resistance of the female"); State v. Dye, 695 N.E.2d 763, 765-66 (Ohio 1998) (interpreting the Ohio rape statute to require that "some amount of force must be proven beyond that force inherent in the crime itself"); Commonwealth v. Berkowitz, 641 A.2d $1161,1164-65$ (Pa. 1994) (finding "a legislative intent that the term 'forcible compulsion' . . . be interpreted as something more than a lack of consent").

11. See Michelle J. Anderson, Reviving Resistance in Rape Law, 1998 U. Il. L. Rev. 953, 1000-01 (citing a number of statutes that include only force in their definition of rape, and a few that include only nonconsent, but concluding that “Id]espite these formal differences. ... in most jurisdictions ... [i]f one, but not the other, is present, the sexual act is not rape").

12. [1976] App. Cas. 182 (appeal taken from Eng. Ct. App.).

13. Id. at 205. The controversy created by the House of Lords' decision ultimately led to adoption of the Sexual Offences (Amendment) Act of 1976, section 1(1) of which provides that "a man commits rape if (a) he has unlawful sexual intercourse with a woman who... does not consent to it; and (b) at the time he knows that she does not consent to the intercourse or he is reckless as to whether she consents to it."

14. Estrich, supra note 4, at 97; see also Lynne Henderson, Getting to Know: 
On the other hand, the decision's supporters responded that "[t]o convict the stupid man would be to convict him for what lawyers call inadvertent negligence," something for which "[p]eople ought not to be punished ... except in some minor offences established by statute."15

In this country, a number of jurisdictions have sided with Morgan's critics, following the California Supreme Court's lead in People v. Mayberry and recognizing a defense only where the defendant's mistaken belief in the victim's consent was both honest and reasonable. ${ }^{16}$ And a few jurisdictions have refused to attach any mens rea requirement to the element of nonconsent, believing that "[t]he crux of the offense" is force and lack of consent and thus, absent some indication to the contrary from the legislature, even an honest, reasonable mistake is no defense. ${ }^{17}$

Honoring Women in Law and in Fact, 2 Tex. J. Women \& L. 41, 67 (1993) (advocating that "the minimum culpable mens rea as to consent should be negligence"); Toni Pickard, Culpable Mistakes and Rape: Relating Mens Rea to the Crime, 30 U. Toronto L.J. 75, 77 (1980) (observing that "it is a major harm for a woman to be subjected to non-consensual intercourse notwithstanding that the man may believe he has her consent," and thus "the cost of taking reasonable care is insignificant compared with the harm which can be avoided through its exercise"). Cf. Schulhofer, supra note 3 , at 258-59 (endorsing this view so long as "the law provides safeguards comparable to those it affords in negligent homicide cases: the defendant's conduct must involve a gross departure from the level of care reasonably expected, and the penalty must be substantially lower than that which applies to intentional misconduct"). But cf. David P. Bryden, Redefining Rape, 3 Buff. Crim. L. Rev. 317, 341 (2000) (commenting that "[i]n rape cases, the distinctions among intentions, recklessness, and negligence are at best exceedingly thin").

15. Glanville Williams, Lords' Decision on the Law of Rape, London Times, May 8, 1975, at 15 .

16. 542 P.2d 1337, 1344-46 (Cal. 1975). See generally Joshua Dressler, Understanding Criminal Law $\$ 33.05$, at 545 (2d ed. 1995) (describing the approach taken in Mayberry as the "general rule" in this country).

17. Commonwealth v. Williams, 439 A.2d 765, 769 (Pa. Super. Ct. 1982); see also Commonwealth v. Ascolillo, 541 N.E.2d 570, 575 (Mass. 1989) (same). Cf. Commonwealth v. Fischer, 721 A.2d 1111, 1114-18 (Pa. Super. Ct. 1998), appeal dismissed, $745 \mathrm{~A} .2 \mathrm{~d} 1214(\mathrm{~Pa} .2000)$ (questioning whether the approach taken in Williams ought to apply in date-rape cases where the victim did not resist). But cf. Beverly Balos \& Mary Louise Fellows, Guilty of the Crime of Trust: Nonstranger Rape, 75 Minn. L. Rev. 599, 606, 607 (1991) (advocating that acquaintance rape should be a matter of strict liability on the grounds that "familiarity encourages a woman to be less wary" and thus creates a "heightened 
What remains largely ignored in these two parallel debates is the relationship between them. Although the actus reus of rape has two critical components-force and absence of consent-issues of mens rea have revolved almost exclusively around the element of nonconsent, that is, the defendant's state of mind with respect to the victim's consent. Very little attention has been paid to the mens rea applicable to the element of force, that is, the defendant's state of mind with respect to the presence of force. For example, in discussing the types of mens rea issues that arise in rape cases, one commentary noted that "the mistake-of-fact defense in a rape prosecution is almost always that the actor thought the victim had consented" and then dropped a footnote to make the point that "[i]t is highly unlikely that a defendant would be mistaken about whether he is having intercourse"-thus completely ignoring the question of mens rea as applied to the element of force. ${ }^{18}$ Another commentator explained that questions of mens rea have begun to surface only recently in rape cases because historically "[a]s a practical matter, the actus reus proved the mens rea"-that is, "[i]f a male used or threatened force to obtain intercourse, then it was evident that he purposely or knowingly had nonconsensual sexual relations"-but then went on to discuss the mens rea issues that have arisen only in terms of nonconsent and not in terms of force. ${ }^{19}$

duty [which] justifies conviction if ... the defendant failed to obtain the victim's consent regardless of the defendant's reasonable or good faith belief'); Henderson, supra note 14 , at 68 (proposing that "the law impose strict liability as soon as the woman says no or indicates that she does not want to engage in sexual activity").

18. Douglas N. Husak \& George C. Thomas III, Date Rape, Social Convention, and Reasonable Mistakes, 11 Law \& Phil. 95, 98 \& n.11 (1992).

19. Dressler, supra note 10, at 431-32; see also Christine L.M. Boyle, Sexual Assault 76 (1984) (discussing the question whether rape defendants must be shown to have intentionally used force, or whether recklessness suffices, and noting that "[ $t]$ his aspect of the mens rea is not an issue in practical terms"); Dressler, supra note $16, \S 33.05$, at 545 (observing that rape is usually considered a general intent crime, such that the defendant must "possess[ a morally blameworthy state of mind regarding the female's lack of consent"); Bryden, supra note 14, at 325 (noting that, "[j]udging by the reported cases, the mens rea issue usually arises by way of defense, when the defendant claims to have been mistaken about the woman's consent"); Vandervort, supra note 4, at 234 
In rape cases involving physical violence or express threats of physical harm, proof of the actus reus obviously does establish mens rea with respect to force as well as nonconsent. A defendant who beat or threatened to kill his victim could hardly raise a plausible argument that he did not know he was using force. But in other circumstances, the defendant's mens rea vis-a-vis force may be less clear, and it may therefore make a difference whether a rape conviction requires proof that the defendant purposely intended to use force, or whether it is enough that he knew he was exercising force, that the woman thought he was using force, or that a reasonable person viewing the situation would have thought so. ${ }^{20}$ Given the traditional criminal law assumption that a mens rea requirement attaches to every material element of a crime, ${ }^{21}$ it seems odd that so little attention has been paid to the question of what mens rea, if any, attaches to the force element.

Admittedly, a handful of courts have paid lip service to this issue, and their opinions are described below in Part II. But the overwhelming majority of court decisions and commentaries discussing mens rea and rape have focused exclusively on the defendant's beliefs and mistakes about the victim's consent. As explained in Part III, this almost universal disregard of mens rea issues as applied to the

(commenting that, "aside from cases of mistake involving minors, all culpability questions which are problematic in rape and sexual assault cases arise in relation to the matter of consent").

20. For specific examples of such cases, see infra notes $125-30$ and accompanying text.

21. See Model Penal Code $\$ 2.02$ cmt. at 231 (Official Draft and Revised Comments 1980) (explaining that "[t]he Model Code's approach is based upon the view that clear analysis requires that the question of the kind of culpability required to establish the commission of an offense be faced separately with respect to each material element of the crime"). See generally Paul H. Robinson \& Jane A. Grall, Element Analysis in Defining Criminal Liability: The Model Penal Code and Beyond, 35 Stan. L. Rev. 681, 683, 757-58 (1983) (noting that although a majority of state legislatures have adopted the Model Penal Code's "element analysis" of mens rea, the courts, "[d]ulled by generations of offense analysis,... continue to define unstated culpability requirements according to their own view of the public policy interests," with "[t]he result ... that in nearly every criminal case in the United States the statement of the law defining the offense charged suffers a significant risk of inaccuracy"). 
element of force confirms the redundancy of the force requirement, once absence of consent and its accompanying mens rea have been established.

\section{THE EXCEPTIONS}

Despite the general tendency on the part of both judges and commentators to ignore mens rea questions in connection with the element of force, courts have occasionally made reference to this issue. As explained below, there is substantial disparity among them as to what sort of mens rea requirement they purport to attach to the force requirement running the gamut from purpose to strict liability. But even in the rare case where the issue is discussed, there is no evidence that the courts' choice of mens rea has any real impact on the outcome of the case. In fact, the few courts that mentioned mens rea in discussing the force requirement typically go on to ignore completely that issue in disposing of the case. Before describing these opinions in Part B, Part A briefly summarizes the rape statutes currently in effect in the various jurisdictions in this country, focusing on any mens rea requirements they impose.

\section{A. The Statutes}

Adhering to traditional formulations of the crime, ${ }^{22}$ the overwhelming majority of contemporary rape statutes contain no explicit mens rea requirement. ${ }^{23}$ The greatest number of them define the crime to encompass intercourse that has been coerced or compelled by force or the threat of

22. See supra text accompanying note 1 .

23. The list below includes the statutory provision in each jurisdiction that comes closest to the traditional definition of forcible rape. Thus, it excludes both aggravated rape statutes that cover, for example, sexual assaults that caused serious bodily harm or involved the use of a weapon and statutes that go beyond the traditional formulation by criminalizing fraud, deception, threats of nonphysical force, and abuses of trust or authority. For an extensive discussion of the latter statutes, see Patricia J. Falk, Rape by Fraud and Rape by Coercion, 64 Brooklyn L. Rev. 39 (1998). 
force. ${ }^{24}$ Some are phrased in slightly different, but similar terms-prohibiting, for example, intercourse by forcible compulsion, ${ }^{25}$ intercourse by force or coercion, ${ }^{26}$ or intercourse by force and against the will of the victim. ${ }^{27} \mathrm{~A}$ few are phrased simply in terms of force, ${ }^{28}$ and a few others

24. Alaska Stat. $\$ \S 11.41 .410,11.41 .470(8)(A)$ (Michie 1998); Conn. Gen. Stat. Ann. $\S 53 a-70$ (West Supp. 2000); Fla. Stat. Ann. $\S \$ 794.011(3)$-(4) (West 2000); Kan. Stat. Ann. § 21-3502 (Supp. 1999) ("overcome by force or fear"); Me. Rev. Stat. Ann. tit. 17-A, $\S \S 253,251(1)(E)$ (West Supp. 1999); Mass. Ann. Laws ch. 265, § 22(b) (Law. Co-op. Supp. 2000); Mich. Comp. Laws Ann. \$\$ 750.520d, 750.520b(1)(f) (West 1991); Neb. Rev. Stat. \$§ 28-319, 28-318(8) (1995); N.H. Rev. Stat. Ann. § 632-A:2 (1996); N.D. Cent. Code § 12.1-20-03 (1997); Okla. Stat. Ann. tit. 21, § 1114 (West Supp. 2000); R.I. Gen. Laws $\$ \$ 11-37-2,11-37-1(2)$ (1994 \& Supp. 1999); Utah Code Ann. \$§ 76-5-402, 76-5-406 (1999 \& Supp. 2000); Wis. Stat. Ann. § 940.225(2)(a) (West Supp. 1999) ("without consent . . . by use or threat of force or violence"); Wyo. Stat. Ann. § 6-2-302(ii) (Michie 1999); see also Vt. Stat. Ann. tit. 13, $\$ 3252$ (1998) ("[c]ompels the other person to participate in a sexual act: (A) [w] ithout the consent of the other person; or (B) [b]y threatening or coercing the other person; or (C) [b]y placing the other person in fear that any person will suffer imminent bodily injury").

25. Ala. Code § 13A-6-61 (1994); Ark. Code Ann. § 5-14-103 (Michie 1997); Ky. Rev. Stat. Ann. § 510.040 (Michie 1996); Mo. Ann. Stat. $\$ 566.030$ (West 1999); N.Y. Penal Law § 130.35 (McKinney 1998); Or. Rev. Stat. § 163.375 (1999); 18 Pa. Cons. Stat. Ann. § 3121 (West Supp. 2000); Wash. Rev. Code Ann. \$ 9A.44.050 (West 2000); W. Va. Code Ann. § 61-8B-4 (Michie 1997).

26. Minn. Stat. Ann. $\$ 609.344$ (West Supp. 2000); N.J. Stat. Ann. § 2C:14-2 (West Supp. 2000); N.M. Stat. Ann. § 30-9-11(E) (Michie Supp. 2000); S.C. Code Ann. § 16-3-654 (Law. Co-op. 1985); S.D. Codified Laws § 22-22-1 (Michie Supp. 2000); Tenn. Code Ann. \$ 39-13-503 (1997).

27. Cal. Penal Code $\S 261(a)(2)$ (West 1999) ("accomplished against a person's will by means of force, violence, duress, menace, or threat of immediate and unlawful bodily injury"); Ga. Code Ann. \$ 16-6-1 (1999) ("forcibly and against her will"); Md. Ann. Code art. 27, $\$ 463$ (1996) ("[b]y force or threat of force against the will and without the consent of the other person"); N.C. Gen. Stat. $\$ 14-27.3$ (1999) ("by force and against the will of the other person"); Va. Code Ann. $§ 18.2$ 61 (Michie Supp. 2000) ("against the complaining witness's will, by force, threat or intimidation"). Cf. Iowa Code Ann. $\S 709.1$ (West 1993) ("by force or against the will of the [victim]"); see also Idaho Code $\$ 18-6101$ (Michie Supp. 2000) (" $[w]$ here she resists but her resistance is overcome by force or violence" or "[w] here she is prevented from resistance by threats of immediate and great bodily harm, accompanied by apparent power of execution"); La. Rev. Stat. Ann. \$ 14:42.1 (West Supp. 2000) ("the victim is prevented from resisting the act by force or threats of physical violence under circumstances where the victim reasonably believes that such resistance would not prevent the rape").

28. D.C. Code Ann. $\$ 22-4102$ (Supp. 2000) ("engages in a sexual act... [b]y using force [or] [b]y threatening or placing [the victim] in reasonable fear" of death, bodily injury, or kidnapping); 720 IIl. Comp. Stat. 5/12-13 (Supp. 2000) ("sexual penetration by the use of force or threat of force"). In both of these 
simply prohibit intercourse without consent. ${ }^{29}$ In none of these formulations is any mental state requirement specified.

Nevertheless, there are a handful of exceptions. Several statutes appear to require proof of knowledge. ${ }^{30} \mathrm{~A}$

jurisdictions, however, consent is expressly recognized as a defense. See D.C. Code Ann. \$22-4107 (1996); 720 Ill. Comp. Stat. 5/12-17(a) (1993).

29. Miss. Code Ann. $\$ 97-3-95$ (2000) ("engages in sexual penetration with ... [a]nother person without... consent"); Nev. Rev. Stat. $\$ 200.366$ (Supp. 1999) ("subjects another person to sexual penetration... against the will of the victim"). See Sanders v. State, 586 So. 2d 792, 796 (Miss. 1991) (noting that while "force or violence are elements that a jury could consider in determining whether the victim consented," "that doesn't mean that force or reasonable apprehension of force are necessary elements of the crime," and therefore approving jury instructions indicating that proof of force or violence was unnecessary); McNair v. State, 825 P.2d 571, 574 (Nev. 1992) (observing that the Nevada rape statute "only requires the commission of the act of sexual penetration against the will of the victim," and therefore "[p]hysical force is not a necessary element in the commission of the crime of rape").

For illustrations of statutes creating lesser offenses for intercourse without consent, see Ala. Code $\$ 13 A-6-65$ (1994) (defining the crime of sexual misconduct as intercourse occurring "without [the victim's] consent"); Fla. Stat. Ann. $\$ 794.011(5)$ (West 2000) ("without that person's consent"); Mo. Ann. Stat. § 566.040 (West 1999) ("sexual intercourse with another person knowing that he does so without that person's consent"); N.D. Cent. Code § 12.1-20-07(1)(a) (1997) ("knowingly has sexual contact" and "knows or has reasonable cause to believe that the contact is offensive to the other person"); Or. Rev. Stat. $\$ 163.425$ (1999) ("Is]ubjects another person to sexual intercourse, deviate sexual intercourse or... penetration ... and the victim does not consent thereto"); $18 \mathrm{~Pa}$. Cons. Stat. Ann. $\$ 3124.1$ (West Supp. 2000) (defining the offense of sexual assault as "sexual intercourse or deviate sexual intercourse ... without the complainant's consent"); Wash. Rev. Code Ann. § 9A.44.060 (West 2000) (creating a lesser offense where "the victim did not consent ... and such lack of consent was clearly expressed by the victim's words or conduct"); Wis. Stat. Ann. § 940.225(3) (West Supp. 1999) (defining third-degree sexual assault to encompass any sexual intercourse or contact "without the consent" of the victim).

30. Ariz. Rev. Stat. $§ 13-1406$ (Supp. 1999) ("intentionally or knowingly engaging in sexual intercourse ... without consent"); Colo. Rev. Stat. Ann. \$ 18-3402 (West 1999) ("knowingly inflicts sexual intrusion or sexual penetration ... if: (a) [t]he actor causes submission of the victim through the actual application of physical force or physical violence; or (b) [t] he actor causes submission of the victim by threat of imminent death, serious bodily harm, extreme pain, or kidnapping"); Haw. Rev. Stat. Ann. \$ 707-730 (Michie 1999) ("knowingly subjects another person to an act of sexual penetration by strong compulsion"); Ind. Code Ann. $\$ 35-42-4-1$ (West Supp. 2000) ("knowingly or intentionally has sexual intercourse with a member of the opposite sex when: (1) the other person is compelled by force or imminent threat of force"); Mont. Code Ann. \$ 45-5-503 (1997) ("knowingly has sexual intercourse without consent"); Tex. Penal Code 
few others are phrased so as to imply a requirement of purpose. ${ }^{31}$ But in the vast majority of jurisdictions, the statutory definitions of rape do not contain an explicit mental state requirement, leaving the question of mens rea to the judiciary. The next section therefore turns to the courts.

\section{B. The Cases}

As outlined above, judges-like legislators-have tended to ignore the question of mens rea as applied to the force requirement in rape cases. Nevertheless, there are a number of cases in which courts have wrestled with this issue. Although they have reached different conclusions, a common thread running through most of these decisions is that the question of mens rea is rarely outcomedeterminative. Rather, the cases tend to be resolved on some basis other than the nature of the defendant's mens rea vis-a-vis force. In analyzing these cases, the discussion below catalogues them according to what mens rea requirement they purport to apply.

\section{Purpose/Intention}

A few courts have suggested that the strictest mens rea requirement attaches to the element of force in rape cases-that is, the prosecution must prove that the defendant purposefully or intentionally used force. Not

Ann. $\$ 22.011$ (Vernon Supp. 2000) (“intentionally or knowingly: (A) causes ... penetration ... without [the victim's] consent"); see also Ohio Rev. Code Ann. $\S$ 2907.03 (Anderson 1999) (creating the lesser offense of sexual battery where the defendant "knowingly coerces the other person to submit by any means that would prevent resistance by a person of ordinary resolution").

31. Del. Code Ann. tit. 11, $\$ 772$ (Supp. 1998) ("[i]ntentionally engages in sexual intercourse with another person, and the intercourse occurs without the victim's consent"); Ohio Rev. Code Ann. $\$ 2907.02$ (Anderson 1999) ("purposely compels the other person to submit by force or threat of force"); see also Wyo. Stat. Ann. \$ 6-2-302(i) (Michie 1999) (alternative formulation of first-degree sexual assault statute, defining the crime as "caus[ing] submission of the victim through the actual application, reasonably calculated to cause submission of the victim, of physical force or forcible confinement") (emphasis added). 
surprisingly-given the express reference to "purpose" in its rape statute ${ }^{32}$-Ohio is one such jurisdiction. ${ }^{33}$ Thus, in State v. Martens, the Ohio Court of Appeals noted that a rape conviction requires proof that the defendant had "the specific intent to purposely compel the victim to submit by force or threat of force." ${ }^{34}$ But the court's opinion went on simply to approve of the definition of "purpose" contained in the jury instructions given at the defendant's trial without applying the mens rea requirement to the facts of the case..$^{35}$

The question of mens rea was directly at issue, however, in another Ohio case, State v. Martin, where the defendant's sole ground for appeal was that "the prosecution failed to prove that he possessed the requisite culpable mental state." 36 The appellate court noted that Ohio case law had established that "a defendant purposely compels his victim to submit by force or threat of force when he uses physical force against the victim, or creates the belief that physical force will be used if the victim does not submit," and that "[ $t]$ he requisite force need not be overt and physically brutal, but can be subtle and psychological." ${ }^{37}$ The court explained that a "two step analysis [was] required to determine if Martin acted purposely under the rape statute." ${ }^{38}$ But neither step directly involved the defendant's state of mind: The first step was "to determine whether Martin engaged in sexual conduct" with the victim, and the second was "to determine whether he compelled her to submit by force or threat of force." In rejecting the defendant's claim and concluding that the trial judge could have reasonably found that Martin "purposely compelled [the victim] to submit ... by

32. See Ohio Rev. Code Ann. $\$ 2907.02$ (Anderson 1999) ("purposely compels the other person to submit by force or threat of force").

33. See State v. Schaim, 600 N.E.2d 661,665 (Ohio 1992).

34. 629 N.E.2d 462, 469 (Ohio Ct. App. 1993).

35. See id. at 469-70.

36. 1995 Ohio App. LEXIS 2078, at $\times 2$ (Ohio Ct. App. May 17, 1995).

37. Id. at *5-6.

38. Id. at $* 4$.

39. Id. 
force or threat of force," the court noted that he "wrapped his arms around [the victim], pinning her body underneath him," when she tried to push him away, that the victim was young, and that there was a disparity between them in terms of age, power, size, and weight. ${ }^{40}$ The court was thereby able to dispose of the case without really discussing the defendant's state of mind, but instead by focusing on the evidence of force and thus talking in terms of actus reus rather than mens rea.

In an earlier case, however, the Ohio Court of Appeals did address the question of mens rea vis-a-vis force in more direct fashion. In that case, State $v$. Wilkens, the court reversed a rape conviction on the grounds that the trial judge had erred in refusing to instruct the jury on the lesser-included offense of sexual battery, a charge distinguishable from rape in that it requires a mens rea of knowledge rather than purpose. ${ }^{41}$ Although the court thought the evidence "overwhelmingly established that appellant had, by threat or use of force, engaged in sexual conduct" with the victim, it also believed that "the jury could have reasonably concluded from the evidence that appellant retained a 'knowing' mens rea, rather than a 'purposeful' mens rea."42 Specifically, the court reasoned that the following evidence might have convinced the jury that the defendant had acted knowingly, but not purposefully: that the victim had known the defendant for five years; that she "voluntarily walked over to [his] house at sometime shortly after midnight"; that a neighbor who heard the incident "at first thought he was simply overhearing a "family affair"; and that the defendant testified that "he had engaged in consensual sexual relations with [the victim] in the past and, on this occasion, she had been the aggressor and had teased both him and

40. Id. at $* 6-7$.

41. 1980 Ohio App. LEXIS 13745, at $* 11$ (Ohio Ct. App. Jan. 17, 1980). See Ohio Rev. Code Ann. $\$ 2907.03$ (Anderson 1999) (defining sexual battery to cover situations where the defendant "knowingly coerces the other person to submit by any means that would prevent resistance by a person of ordinary resolution").

42. Wilkens, 1980 Ohio App. LEXIS 13745, at *14, $* 12$. 
earlier his cousin."43 Although the court did not explain exactly how this evidence could have led to the jury to convict the defendant on a sexual battery charge, it may have thought that the prior friendly relationship between the parties suggested that the defendant may not have wanted to compel the victim to submit, even though he was aware that he was doing so. ${ }^{44}$

A few other courts seem to have endorsed a mens rea requirement of purpose despite the absence of statutory language mandating that result. In State v. Rusk, for example, the Maryland Court of Appeals indicated that the force requirement could be satisfied "without violence," so long as "the acts and threats of the defendant were reasonably calculated to create in the mind of the victim ... a real apprehension ... of imminent bodily harm." 45 The

43. Id. at *13-14.

44. Aside from Ohio, Delaware is the only other state whose rape statute expressly suggests a mens rea requirement of purpose. The Delaware rape statute includes the mens rea term "intentionally," although the wording of that statute makes it less clear precisely what elements of the crime the term modifies. See Del. Code Ann. tit. 11, $\$ 772$ (Supp. 1998) ("[i]ntentionally engages in sexual intercourse with another person, and the intercourse occurs without the victim's consent"); id. $\$ 761(\mathrm{~h})(1)$ (defining "without consent" to include cases where "[t]he defendant compelled the victim to submit" by coercion, force, threat, or "any other means which would compel a reasonable person under the circumstances to submit"). In Getz v. State, 538 A.2d 726 (Del. 1987), the Delaware Supreme Court made the observation that, "[w] the burden of proving intent, as an element of the offense of rape first degree, the requisite state of mind is demonstrated by proof of the defendant's 'conscious object to engage in conduct of that nature." Id. at 733 (quoting Del. Code Ann. tit. $11,8231(a)(1)$ ). But the court provided no further analysis or explanation of the mens rea requirement or its applicability to the element of force, disposing of the case by ruling that evidence of the defendant's prior sexual contact with his daughter was inadmissible.

45. 424 A.2d 720, 726 (Md. 1981) (quoting Hazel v. State, 157 A.2d 922, 925 (Md. 1960)) (emphasis added). The court's use of the word "reasonably" creates some confusion by suggesting a negligence mens rea, while the term "calculated" connotes purpose. The dissenting opinion in Rusk lends support to the latter interpretation, observing that the victim "must resist unless the defendant has objectively manifested his intent to use physical force to accomplish his purpose." Id. at 733 (Cole, J., dissenting); see also Martin v. State, 686 A.2d 1130, 1159 (Md. Ct. Spec. App. 1996) (affirming the trial court's finding that the defendant "reasonably intended to create the circumstances that produced [the victim's] reasonable fear of physical harm," noting that he "deliberately placed the victim in a situation where she would be afraid, with the expectation she would thereby 
court later commented that the jury could reasonably have found that "the taking of [the victim's] car keys was intended by Rusk to immobilize her alone, late at night, in a neighborhood with which she was not familiar."46 But aside from that brief reference, the court ignored the mens rea issue in finding sufficient evidence of force to support Rusk's conviction. In explaining its decision, the court placed "particular focus" on the fact that the defendant "put his hands on [the victim's] throat and began 'lightly to choke' her,"47 without addressing the question of what his state of mind was at that particular moment and without responding to the appellate court's observation that "the 'light choking' could have been a heavy caress." ${ }^{\prime 8}$

yield to his lustful demands without physical resistance") (emphasis added) (quoting Walter v. State, 264 A.2d 882, 887 (Md. Ct. Spec. App. 1970)); Chavez v. State, 601 P.2d 166, 172 (Wyo. 1979) (interpreting a statutory provision containing the "reasonably calculated" language, see supra note 31 , and finding insufficient evidence of the defendant's "intent to cause submission by forcible confinement").

46. Rusk, 424 A.2d at 728 (emphasis added).

47. Id.

48. Rusk v. State, 406 A.2d 624, 628 (Md. Ct. Spec. App. 1979), rev'd, 424 A.2d 720 (Md. 1981); see also Estrich, supra note 4, at 65-66 (criticizing the court's "emphasis on the light choking/heavy caresses," commenting that "[i]t was not the only force that produced [the] moment," but "the only force that a schoolboy might recognize").

Several California appellate court opinions have likewise suggested that a rape conviction requires proof of "the intent to sexually penetrate the victim and the intent to accomplish that act by force or fear." People v. Balcom, 1 Cal. Rptr. 2d 879, 885 (Ct. App. 1991), affd on other grounds, 867 P.2d 777 (Cal. 1994); People v. Burnham, 222 Cal. Rptr. 630, 635 (Ct. App. 1986); see also People v. Tassell, 679 P.2d 1, 10 (Cal. 1984) (Reynoso, J., concurring and dissenting) (same). But the question of mens rea vis-a-vis force did not figure in the disposition of those cases, as Balcom involved the admissibility of the defendant's prior rape conviction, see 1 Cal. Rptr. $2 d$ at 883-86, and Burnham turned on the court's analysis of the defendant's mistake of fact defense concerning nonconsent, not force, see 222 Cal. Rptr. at 634-42. Moreover, more recent California case law treats rape as a general intent crime. See infra note 92.

For a description of another case that seems to require proof of a purposeful use of force, see the discussion of People v. Evans infra at notes 113-16 and accompanying text. 


\section{Knowledge}

Other courts have suggested that less stringent mens rea requirements apply to the force requirement in rape cases. Some have apparently endorsed a knowledge mens rea, including courts in three states-Hawaii, Indiana, and Texas-where the rape statutes expressly support that requirement. ${ }^{49}$

In State $v$. Keomany, ${ }^{50}$ for example, the Hawaii Intermediate Court of Appeals noted that its first-degree sexual assault statute makes it a crime to "knowingly subject[] another person to an act of sexual penetration by strong compulsion."51 The defendant in that case challenged the instructions given to the jury, arguing that they failed to indicate that "the specified state of mind, 'knowingly,' applied to each element of the offense." 52 The appellate court agreed that "strong compulsion" was an attendant circumstance element of the crime and thus required proof of knowledge. ${ }^{53}$ But the court then focused on the defendant's state of mind vis-a-vis lack of consent, not compulsion, noting that mens rea would be established and the defendant would be deemed to have "acted knowingly with respect to the relevant attendant circumstance $[$ if ... he was aware Complainant did not consent." ${ }^{54}$ And the court disposed of the case by concluding that the jury instructions were adequate, without evaluating how the mens rea requirement applied

49. See supra note 30 . For a description of the relevant case law in the three other states whose statutes seem to require proof of knowledge, see infra note 65 .

50. 2000 Haw. App. LEXIS 112 (Haw. Ct. App. June 5, 2000), cert. granted, 2000 Haw. LEXIS 222 (Haw. July 7, 2000).

51. Haw. Rev. Stat. Ann. $\$ 707-730(1)(a)$ (Michie 1999); see also id. $\$ 707-700$ (defining "strong compulsion" as "the use or attempt to use" either "physical force," a "dangerous instrument," or a threat of bodily injury or kidnapping "to overcome" the victim).

52. Keomany, 2000 Haw. App. LEXIS 112 , at $* 14$.

53. See id. at *16-17, 21. Cf. State v. Arceo, 928 P.2d 843, 857 (Haw. 1996) (noting that the crime of third-degree sexual assault, a form of statutory rape, requires proof of knowledge of the attendant circumstance that the defendant was not married to the victim).

54. Keomany, 2000 Haw. App. LEXIS 112 , at $* 17$. 
to the facts before it. ${ }^{55}$

Similarly, in Tyson $v$. State, the Indiana Court of Appeals approved jury instructions that, mirroring the state's rape statute, required the prosecution to prove that the defendant "knowingly or intentionally used force to have sexual contact with [the victim] when [she] was compelled by the force." But the court's discussion arose in the context of evaluating the defendant's alleged mistake of fact about the victim's consent and not his mens rea with respect to force. ${ }^{57}$

The Texas sexual assault statute likewise requires proof that the defendant "intentionally or knowingly... cause[d] the penetration" of the victim "without that person's consent." to include circumstances where a defendant "compels the other person to submit or participate by the use of physical force or violence" or "by threatening to use force or violence [where] the other person believes that the [defendant] has the present ability to execute the threat." The wording of the statute makes it unclear precisely what elements the mens rea terms "intentionally or knowingly" modify. In Murray v. State, however, the Texas Court of Appeals suggested that the mens rea requirements apply to the use of force. ${ }^{60}$ In that case, the court upheld jury instructions that advised the jurors to return a guilty verdict if they found that the defendant had intercourse with the victim "intentionally or knowingly, by the use of physical force or violence or by threatening to use force or violence... and without the [victim's] consent." 11 The appellate court explained that criminal statutes can contain one or more of

55. See id. at *7-27.

56. 619 N.E.2d 276, 298 (Ind. Ct. App. 1993). For a description of an Indiana opinion taking a different view of the requisite mens rea, see the discussion of Tobias v. State infra at notes 109-12 and accompanying text.

57. See Tyson, 619 N.E.2d at 292-98.

58. Tex. Penal Code Ann. § 22.011(a)(1) (Vernon Supp. 2000); see also id. § $22.021(a)(1)$ (using identical language in defining aggravated sexual assault).

59. Id. § 22.011(b)(1)-(2).

60. 804 S.W.2d 279 (Tex. Ct. App. 1991).

61. Id. at 280 . 
three types of "conduct elements"-those involving the nature of the defendant's conduct, the results of that conduct, or the circumstances surrounding the conduct. Although the court ultimately thought it unclear whether the crime of sexual assault was defined simply in terms of the nature of a defendant's conduct or also its results, ${ }^{62}$ the court observed that "it is those essential 'conduct elements' to which a culpable mental state must apply."63 But this discussion appeared in the course of the court's analysis of the defendant's challenge to jury instructions that generally defined the terms "intentionally" and "knowingly,"64 and the court therefore had no need to determine whether the defendant in that case had intentionally or knowingly used force. ${ }^{65}$

62. Cf. Cook v. State, 884 S.W.2d 485, 493 n.5 (Tex. Crim. App. 1994) (Maloney, J., concurring) (noting that, for the crime of aggravated sexual assault, "causes the penetration" could be considered either a result element or a pure conduct element, while lack of consent could be deemed either a circumstance or a conduct element); Redo v. State, 1998 Tex. App. LEXIS 2382, at *2 (Tex. Ct. App. Feb. 27, 1998) (observing that "[w] hether aggravated sexual assault is a natureof-conduct or result-of-conduct or combined offense has not been definitively settled"). But cf. Myers v. State, 1997 Tex. App. LEXIS 410, at *11-12 (Tex. Ct. App. Jan. 31, 1997) (taking the position in a case involving charges of aggravated sexual assault of a child that "the nature of appellant's conduct and the result of the conduct are the same-contact or penetration of [the victim's] sexual organ").

63. Murray, 804 S.W.2d at 281.

64. The defendant maintained that the trial judge "should have limited the definition of the term 'intentionally' to the results of his conduct as opposed to the nature of his conduct." Id. at 280.

65. Although the rape statutes in three other states-Arizona, Colorado, and Montana-also seem to require proof of knowledge, see supra note 30 , the case law in those jurisdictions is less clear. In State v. White, 770 P.2d 328 (Ariz. 1989), the Arizona Supreme Court noted that the state's sexual assault statute requires proof that the defendant "intentionally or knowingly engaged in nonconsensual sexual intercourse." Id. at 338 (quoting State v. Rybolt, 650 P.2d 1258, 1263 (Ariz. Ct. App. 1982). But it did so in the context of upholding the trial court's decision to impose consecutive sentences for burglary and sexual assault, and therefore offered no further explanation of the mens rea required for sexual assault. Moreover, in State v. Cartwright, 746 P.2d 478, 482 (Ariz. 1987), the court listed the three elements of sexual assault as follows: "1) [e]ngaging in sexual intercourse... with another person; 2) [k]nowingly; 3) [a]nd without consent of such person." In finding sufficient evidence of mens rea in that case, the court noted that "Id]efendant's participation in the intercourse creates a presumption that he did so knowingly," citing in support State v. Jamison, 517 P.2d 1241, 1244 (Ariz. 1974), for the proposition that "general intent [is] 
A few courts have attached a knowledge mens rea to the element of force despite the absence of statutory language supporting that choice. In State $v$. Ayer, for example, the New Hampshire Supreme Court noted that the state's rape statute contained no express mens rea requirement and therefore turned for guidance to "the common-law origins of the crime."'66 Observing that rape was historically considered a general intent crime, and that the New Hampshire legislature had followed the Model

presumed from the commission of the crime itself." 746 P.2d at 483 ; see also State v. Williams, 554 P.2d 646, 651 (Ariz. Ct. App. 1976) (describing rape as a general intent crime).

In Chambers v. People, 682 P.2d 1173 (Colo. 1984), the Colorado Supreme Court observed that "[t]he offense of first degree sexual assault requires that the actor have an awareness of his conduct and of the circumstance of the nonconsent of his victim." Id. at 1178; see also People v. Krovarz, 697 P.2d 378, 383 (Colo. 1985) (observing in dictum that "[t]he culpable mental state relative to the conduct and result comprised within first-degree sexual assault was, and still is, knowledge"). The defendant in Chambers, however, was challenging the sufficiency of jury instructions defining the term "knowingly," and the court therefore did not need to evaluate whether the mens rea requirement was met on the facts of that case. 682 P.2d at 1178-79. The court subsequently interpreted its holding in Chambers as requiring proof of the defendant's "awareness of engaging in certain prohibited acts which the statute equates to nonconsent." Dunton v. People, 898 P.2d 571, 573 n.2 (Colo. 1995). Although these rulings suggest that the prosecution must prove that the defendant knowingly used force, Dunton held that a trial judge need not instruct the jury that the crime requires proof that the defendant was aware of the victim's nonconsent, noting that the statute "prohibits conduct which by its very nature negates the existence of the victim's consent" and thus "an independent showing of the defendant's awareness of nonconsent by the victim is unnecessary." Id. at 573. Most recently, in People v. Rodriguez, 914 P.2d 230 (Colo. 1996), the court upheld jury instructions defining the crime of first-degree sexual assault, noting that the jury was adequately informed that the statute's mens rea requirement of knowledge "modifie[d] all succeeding conduct elements" of the crime-including, presumably, the requirement that the defendant "caused [the victim's] submission ... through the actual application of physical force or physical violence." Id. at 272. But that was the end of the court's mens rea discussion.

The three justices who dissented from the Montana Supreme Court's decision in State v. Keys, 852 P.2d 621 (Mont. 1993), observed, in the course of discussing the admissibility of the defendant's prior conviction for indecent exposure, that "[t]he requirement on the part of the trier of fact [in a rape trial is] to determine whether or not the defendant knowingly or purposely committed sexual intercourse without consent." Id. at 628 (Weber, J., dissenting). But there was no further discussion of mens rea in the opinion.

66. 612 A.2d 923, 925 (N.H. 1992) (quoting State v. Aldrich, 466 A.2d 938, 941 (N.H. 1983)). 
Penal Code's approach to mens rea and "discarded" the concept of specific and general intent crimes, ${ }^{67}$ the court concluded that requiring proof of knowledge would "adequately protect [the defendant] from criminal prosecution for innocent conduct." ${ }^{\prime \prime 8}$ Although the court did not provide any further guidance as to which elements of the crime the knowledge mens rea requirement applied, the court indicated in a later opinion, State v. Bassett, that the prosecution must prove that the defendant "knowingly committed each element of the offenses charged."69 Given that the court made that statement immediately after noting that Bassett was charged with "sexual penetration... by the actual use of physical force or violence and superior physical strength ... and by coercing [the victim] to submit through threats of violence," the court presumably meant to extend the knowledge requirement to the element of force. ${ }^{70}$ But the Bassett opinion revolved around evidentiary issues concerning the admissibility of the defendant's prior sexual assault conviction, and not the sufficiency of the evidence of mens rea. $^{71}$

67. For a description of the specific/general intent dichotomy, see infra notes 81.96 and accompanying text.

68. Ayer, 612 A.2d at 925 .

69. 659 A.2d 891,896 (N.H. 1995).

70. Id.

71. See id. at 895-98. The West Virginia Supreme Court has also hinted that it may support a mens rea requirement of knowledge. In two cases involving allegations that the forcible compulsion required by the state's sexual assault statute came from someone other than the defendants, the court found sufficient evidence to support a finding that the defendants were "aware" that the third party had used "forcible compulsion... which coerced the victim" to have intercourse with them. State v. Miller, 466 S.E.2d 507, 513 (W. Va. 1995); see also State v. Hottinger, 461 S.E.2d 462, 469 (W. Va. 1995). In neither of these cases, however, had the defendant objected to jury instructions defining the term "forcible compulsion" to include force or intimidation that the defendant knew had been exerted by a third person, and the court therefore declined to rule on the propriety of that definition. See Miller, 466 S.E.2d at 513 n.3; Hottinger, 461 S.E.2d at 468 n.4. For a description of two Oregon cases that also use the term "knowingly," see infra note 79 . 


\section{Recklessness}

Although none of the rape statutes currently in effect explicitly adopt a mens rea requirement of recklessness, ${ }^{72}$ several courts have seemingly chosen to require proof of recklessness vis-a-vis the force requirement. In reaching that result, these courts have relied on provisions in their state criminal codes modeled on section 2.02(3) of the Model Penal Code, which requires proof of at least recklessness in cases where a criminal statute fails to specify a mens rea requirement.

In State v. Bryant, for example, the Missouri Court of Appeals reasoned that because the statutory definition of rape contains no mens rea language, the prosecution must prove a mental state of at least recklessness. ${ }^{73}$ Accordingly, the court upheld instructions advising the jurors to convict if they found sufficient evidence that the defendant "knew that sexual intercourse was being accomplished without the consent of [the victim] by forcible compulsion or consciously disregarded a substantial and unjustifiable risk that sexual intercourse was being accomplished without the consent of [the victim] by forcible compulsion. ${ }^{24}$ Although this language clearly implies that the recklessness requirement applies both to lack of consent and forcible compulsion, the decision goes on to note that such instructions must be given in cases where consent or mistakes about consent are at issue, without mentioning the question of mens rea vis-a-vis force. ${ }^{75}$ And the court

72. See supra notes 22-31 and accompanying text.

73. 756 S.W.2d 594, 597 (Mo. Ct. App. 1988) (holding that "[r]ape must be committed either recklessly or knowingly, negligence is not enough") (citing Mo. Rev. Stat. § 76-2-102 (1953), a default rule similar to $\$ 2.02(3)$ of the Model Penal Code).

74. Id. at 596.

75. See id.; see also State v. Foster, 631 S.W.2d 672, 675-76 (Mo. Ct. App. 1982) (same). There are indications in other Missouri decisions, however, that the mens rea required in rape cases is something other than recklessness. In State v. Koonce, 731 S.W.2d 431, 438 (Mo. Ct. App. 1987), the court held that a defendant's mistaken belief in the victim's consent must be both honest and reasonable in order to afford a defense, implying a mens rea of negligence at least with respect to the element of nonconsent. And in State v. Harris, 620 S.W.2d 
disposed of the case by approving of the jury instructions, without providing further guidance as to how the mens rea requirement might be applied either generally or on the facts of that case. ${ }^{76}$

349 (Mo. 1981), the court suggested that rape is a general intent crime, noting that in cases where the element of force is proven, no intent is necessary "other than that evidenced by the doing of the acts constituting the offense." Id. at 355 (quoting State v. Tompkins, 277 S.W.2d 587, 591 (Mo. 1955)).

76. Courts in several other jurisdictions have relied on default rules similar to $\$ 2.02(3)$ of the Model Penal Code to justify requiring proof of recklessness when the rape statute does not include a mens rea term. See State v. Cummins, 347 N.W.2d 571, 572 (N.D. 1984) (citing N.D. Cent. Code $\$ 12.1-02-02(2)$, but then focusing on the defendant's intoxication defense and the need to define the terms "purpose" and "knowledge" in the jury instructions, rather than elaborating on the nature of the mens rea requirement); State v. Calamity, 735 P.2d 39, 43 (Utah 1987) (citing Utah Code Ann. $\$ 76-2-102$, but offering no further analysis of the reach of the mens rea requirement).

Likewise, the Illinois Supreme Court recently ruled that the legislature's failure to specify a mens rea requirement in the aggravated criminal sexual assault statute means that "a mental state of intent, knowledge or recklessness must be implied." People v. Simms, 736 N.E.2d 1092, 1114 (Ill. 2000) (citing 720 Ill. Comp. Stat. 5/4-3(b) (1993)). But the court went on to suggest that it considers sexual assault a general intent crime when it refused to require trial judges to issue jury instructions on mens rea, observing that the crime's state of mind requirements "are in the nature of general criminal mental states ... which almost always accompany the acts alleged." Id. For a description of other Illinois decisions that use similar language and clearly classify sexual assault as a general intent crime, see infra note 94 and accompanying text. But cf. People v. Smith, 614 N.E.2d 1326, 1332 (Ill. App. Ct.), vacated on other grounds, 620 N.E.2d 417 (Ill. 1993) (noting that "a mental state of intent to commit, or knowledge of committing, an act of sexual penetration" is "[i]mplicit" in the definition of aggravated sexual assault, but rejecting any requirement of mens rea with respect to the aggravating factor that the crime "caused bodily harm," and therefore concluding that it was "immaterial that defendant may not have known he was transmitting, or that he may not have intended to transmit, a sexual disease to the victim").

For a case relying on a default rule similar to $\S 2.02(3)$ of the Model Penal Code to justify requiring proof of recklessness with respect to the element of nonconsent, see Reynolds v. State, 664 P.2d 621, 625 (Alaska Ct. App. 1983) (concluding that "the state must prove that the defendant knowingly engaged in sexual intercourse and recklessly disregarded his victim's lack of consent," without mentioning the issue of mens rea as to force-even though absence of consent was defined by statute to mean "coerced by the use of force" or the threat of force). 


\section{Negligence}

Although, once again, none of the contemporary rape statutes expressly incorporates a mens rea requirement of negligence, ${ }^{77}$ the Oregon Court of Appeals' decision in State $v$. Wasson suggested that negligence may be the appropriate mens rea for the force requirement. ${ }^{78}$ In that case, the court observed that a defendant must "commit each of the material elements of the crime [of rape] either intentionally, knowingly, recklessly, or with criminal negligence." ${ }^{\text {B }}$ But the court made that comment in the context of addressing the admissibility of evidence that the defendant had attempted to rob a store prior to the attempted rape at issue there, and the court did not elaborate further on the mens rea issue. ${ }^{80}$

\section{General Intent}

Following the traditional common law definition of the crime, and given the absence of mens rea language in most rape statutes, ${ }^{81}$ a substantial number of courts have held that rape is a general intent crime, as opposed to a specific

77. See supra notes $22-31$ and accompanying text.

78. 607 P.2d 792 (Or. Ct. App. 1980).

79. Id. at 794 n.5 (citing Or. Rev. Stat. $\$ \S 163.375,161.115(2)$ ). But cf. State v. Bunyea, 606 P.2d 685, 687 n.6 (Or. Ct. App. 1980) (observing-in the context of addressing a defense of mistaken consent-that the indictment in that case alleged that the defendant "did unlawfully and knowingly, by forcible compulsion, engage in sexual intercourse," and defining "knowingly" to require that "the defendant was aware that he was using force to compel the victim to submit"); see also State v. Francis, 588 P.2d 611, 612 n.1, 614 (Or. 1978) (likewise noting-in the context of upholding the trial judge's refusal to give the defendant's requested instruction on "intent" - that the indictment alleged that the defendant "unlawfully and knowingly, by forcible compulsion, engage[d] in sexual intercourse," and therefore "an instruction worded in terms of 'intent' should not be given in a prosecution for a crime where the indictment alleges "knowledge").

80. Cf. Reynolds v. State, 664 P.2d 621, 630 n.3 (Alaska Ct. App. 1983) (noting that one of the aggravating factors about the crime that the trial judge found relevant in sentencing the defendant was that he "should have known that Ia handgun left in clear view near the bed] would intimidate" the victim even though the judge "did not find that Reynolds intentionally relied on the gun to intimidate her") (emphasis added).

81. See supra notes $22-31$ and accompanying text. 
intent crime. ${ }^{82}$ But these courts have not all used the term "general intent" in the same way, thus confirming the widespread criticism of the general/specific intent dichotomy as confusing and vague. ${ }^{83}$ Some courts seem to define general intent crimes as those requiring proof of knowledge rather than purpose, ${ }^{84}$ therefore effectively aligning those jurisdictions with those that have adopted a knowledge mens rea for rape cases. By contrast, another court has used the term "general intent" to mean that "no knowledge is required for the element of force or coercion."\$5 And at least one court has defined general intent crimes as those for which "the only intent required is one of conscious wrongdoing." 86

Adding to the confusion, some courts have simultaneously incorporated a number of different notions into the concept of "general intent" when discussing the

82. See, e.g., Stokes v. State, 648 So. 2d 1179, 1181 (Ala. Crim. App. 1994) (observing that "Irlape in the first degree does not require proof of specific intent"); State v. Crawford, 672 So. 2d 197, 210 (La. Ct. App. 1996) (noting that "specific intent is not an essential element of aggravated rape"). See generally Dressler, supra note $16, \S 33.05$, at 545 .

83. See, e.g., People v. Hood, 462 P.2d 370, 377 (Cal. 1969) (noting that "[s]pecific and general intent have been notoriously difficult terms to define and apply"); Dressler, supra note 16, $\$ 10.06$, at 118-19 (calling the terms "the bane of criminal law students and lawyers," in part because "there is no universally accepted meaning to the terms"); Sanford H. Kadish \& Stephen J. Schulhofer, Criminal Law and Its Processes: Cases and Materials 218 (6th ed. 1995) (observing that the terms "have been the source of endless confusion in the courts" and "are often used inconsistently").

84. See State v. Ayer, 612 A.2d 923, 925 (N.H. 1992).

85. People v. Brown, 495 N.W.2d 812, 813 (Mich. Ct. App. 1992) (per curiam). But cf. People v. Corbiere, 559 N.W.2d 666, 669 (Mich. Ct. App. 1996) (citing Brown for the proposition that a general intent crime is "proved by showing that the defendant committed a proscribed sexual act").

86. State v. Duncan, 830 P.2d 554, 562 (N.M. Ct. App. 1990), affd on other grounds, 805 P.2d 621 (N.M. 1991) (holding that criminal sexual penetration in the second degree, which requires proof of force or coercion that causes physical injury, is not a specific intent crime); see also State v. Campos, 921 P.2d 1266, 1277 (N.M. 1996) (defining a general intent crime as one that involves "conscious wrongdoing or the purposeful doing of an act that the law declares to be a crime") (emphasis added). But cf. People v. Osband, 919 P.2d 640, 681 (Cal. 1996) (noting that because rape is a general intent crime, the defendant need not have intended to violate the law, and explaining that, "[w]hen a person intentionally does that which the law declares to be a crime, he is acting with general criminal intent, even though he may not know that his act or conduct is unlawful"). 
mens rea required for rape. In State v. Cantrell, for example, the Kansas Supreme Court approved language from a prior dissent which indicated that because "specific intent is not a genuine issue in a rape case" and the prosecution must establish that the victim "was overcome by force and subjected to sexual intercourse without consent," "[i]t is her intent and state of mind which is of supreme importance." ${ }^{\prime 87}$ But the court also suggested that the defendant's state of mind was significant when it observed that the defendant must have "voluntarily committed the act of forcible sexual intercourse" ${ }^{\text {"88 }}$ and that his conduct must have been "intentional," that is, "willful and purposeful and not accidental."'s9 Despite this language, the court went on to reject the defendant's contention that his conviction could not stand unless he was "aware of the victim's resistance and intended to engage in intercourse despite that resistance," noting that for crimes that make no "express reference to intent," it is enough "simply to allege the commission of the act ... and the intent will be presumed."'90

87. 673 P.2d 1147, 1153 (Kan. 1983) (quoting State v. Gonzales, 535 P.2d 988, 990 (Kan. 1975) (Prager, J., dissenting)).

88. Id. (quoting Gonzales, 535 P.2d at 990 (Prager, J., dissenting)).

89. Id. at 1152 (quoting the jury instructions); see also State v. Esher, 922 P.2d 1123, 1126 (Kan. Ct. App. 1996) (observing that, even for general intent crimes, the state's criminal statutes make "a criminal intent... an essential element," requiring "[p]roof of intentional conduct...., unless the statute defining the crime expressly provides that the prohibited act is criminal if done in a reckless manner," and distinguishing specific intent crimes as those that require in addition "a further particular intent which must accompany the prohibited acts") (quoting State v. Sterling, 680 P.2d 301, 303 (Kan. 1984)).

90. Cantrell, 673 P.2d at 1155, 1154 (quoting State v. Cruitt, 436 P.2d 870, 873 (Kan. 1968)).

Subsequent decisions by the Kansas Supreme Court have not alleviated the confusion. On the one hand, the court has persisted in rejecting any requirement that the prosecution prove that a rape defendant "intended to have nonconsensual intercourse," noting that the statute only requires proof of "sexual intercourse without the victim's consent when the victim was overcome by force or fear," and therefore "[w]hether [he] thought his victim consented or was not fearful is irrelevant if the State proved that she did not consent and was overcome by fear." State v. Plunkett, 934 P.2d 113, 118 (Kan. 1997). On the other hand, the court has suggested that the prosecution must demonstrate that the defendant's "sexual conduct was willful and purposeful and, thus, intentional." 
Despite these variations in the courts' use of the term "general intent," most courts that consider rape a general intent crime pick up on the portion of the court's opinion in Cantrell that defines general intent crimes as those requiring "only a general intent to perform the physical acts that constitute [the] crime," and not "a specific intention to have intercourse without the consent of the victim."1 Thus, as a general intent crime, rape does not require proof of " a special mental element ... beyond any

Id.

The Washington Court of Appeals has likewise used differing notions of the concept of general intent. In State v. Walden, 841 P.2d 81, 83 (Wash. Ct. App. 1992), the court observed that the crime of second-degree rape-defined as sexual intercourse by forcible compulsion- "includes no element of intent" and therefore allows convictions "without proof of the existence of any mental state." But the court also noted that "our courts have consistently rejected the argument that intent or knowledge is an implied element of the crime of rape," thereby perhaps leaving open the possibility of a recklessness or negligence mens rea requirement. Id. at 83-84; see also State v. Brown, 899 P.2d 34, 35 (Wash. Ct. App. 1995) (same). At another point, however, the Walden opinion-like the Kansas Supreme Court's opinion in Cantrell-suggested that the victim's state of mind is the key, explaining that "the only mental state explicit in the definition of forcible compulsion is the victim's 'fear of death or physical injury." 841 P.2d at $84 \mathrm{n} .2$ (quoting Wash. Rev. Code \$9A.44.010(6)). Nevertheless, the court indicated that the defendant's state of mind continues to be relevant when it reasoned that "the Legislature criminalized particular conduct-the use of physical force or the threat of physical harm-as a means of inducing nonconsensual intercourse" and "[s]ince one cannot accidentally or innocently induce another person to engage in sexual intercourse by means of force or threat, there is no need to imply specific intent as an element of the crime in order to prevent nonculpable conduct from being criminal." Id. at 84 . "Requiring proof that the actor intended to forcibly compel intercourse," the Walden court feared, "would lead to the troubling result that a perpetrator could be exonerated by arguing that he did not intend to overcome resistance or did not intend his conduct as an express or implied threat." Id.; see also State v. Brown, 899 P.2d 34, 36 (Wash. Ct. App. 1995) (same). Exacerbating the confusion, the Washington Court of Appeals has on other occasions suggested that the prosecution must demonstrate the defendant's intent to exert force. See State v. Weisberg, 829 P.2d 252, 255 (Wash. Ct. App. 1992) (holding that in cases where the evidence of forcible compulsion involves merely an implied threat, "a finding of forcible compulsion cannot be based solely on the victim's subjective reaction to particular conduct," but also requires evidence that the defendant "in some way communicated his intention to inflict physical injury in order to coerce compliance") (emphasis added); State v. McKnight, 774 P.2d 532, 535 (Wash. Ct. App. 1989) (ruling that proof of forcible compulsion requires evidence that "the force exerted was directed at overcoming the victim's resistance") (emphasis added).

91. State v. Smith, 554 A.2d 713, 715-16 (Conn. 1989). 
mental state required with respect to the actus reus of the crime." 92

But the element of force is part of the actus reus-one of the "physical acts that constitute the crime"-and therefore some mens rea requirement should presumably attach to the force element in these jurisdictions. According to a number of these courts, however, the mens rea is inextricably tied to the actus reus, such that proof of force necessarily implies proof of the requisite mens rea. As the Massachusetts Appeals Court put it:

[A] finding by the jury based upon the behavior of the defendant and the victim in a rape case that the sexual encounter was against the will, or without the consent of, the victim of necessity implies a finding of general intent without a separate instruction on that issue. So formulated, the crime is "based on the premise that one person cannot accidentally or innocently induce another person to engage in sexual intercourse by means of [force or] a threat. ${ }^{.93}$

Similarly, in the words of the Illinois Appellate Court, "[i]t is obvious that the commission of the general intent crime[ of criminal sexual assault . . . necessarily implies an intent or knowledge." Implicitly, then, these courts seem

92. State v. Lopez, 892 P.2d 898, 900-01 (Idaho Ct. App. 1995) (holding that rape is not a specific intent crime) (quoting 1 Wayne $R$. LaFave \& Austin W. Scott, Jr., Substantive Criminal Law § 3.5(e), at 315 (1986)); see also People v. Osband, 919 P.2d 640, 681 (Cal. 1996) (observing that rape is a general intent crime and therefore "performing a proscribed act was enough to violate the law"); State v. Lamphere, 348 N.W.2d 212, 217 (Iowa 1984); Commonwealth v. Grant, 464 N.E.2d 33, 36-35 (Mass. 1984); State v. Hart, 477 N.W.2d 732, 736 (Minn. Ct. App. 1991) (reasoning that the crime of first-degree criminal sexual conduct is a general intent crime because the statute contains no "intent requirement," and thus "[t]he intent required ... is the intent to do the act that constitutes the crime"); Roberson v. State, 501 So. 2d 398, 401 (Miss. 1987); State v. Koperski, 578 N.W.2d 837, 847 (Neb. 1998) (explaining that "[a]s a general intent crime, criminal intent is inferred from the commission of the acts constituting the elements of the crime"); State v. Daughtry, 459 S.E.2d 747, 761 (N.C. 1995); Boyd v. State, 572 P.2d 276, 279 (Okla. Crim. App. 1977); Bryan v. State, 745 P.2d 905, 909 (Wyo. 1987).

93. Commonwealth v. Lefkowitz, 481 N.E.2d 227, 231 n.12 (Mass. App. Ct. 1985) (quoting State v. Saucier, 421 A.2d 57, 59 (Me. 1980)).

94. People v. Bock, 611 N.E.2d 1173, 1187 (nll. App. Ct. 1993) (quoting People 
to be saying that the crime of rape involves a purposeful or knowing use of force. ${ }^{95}$ At the same time, however, they balk at any suggestion that the prosecution must establish that mens rea, refusing to demand proof that a rape defendant "had sexual intercourse with the intent that it be by force or threat of bodily injury and against the victim's will. ${ }^{m 96}$

However these various courts define the term "general intent," their opinions do not shed any more light on the way in which a mens rea requirement might apply to the element of force than the other decisions described in the prior sections. These cases tend to involve questions about the defendant's right to a jury instruction on intoxication or some other defense ${ }^{97}$ or on a lesser-included offense, ${ }^{98}$ the wording of the jury instructions on mens rea, ${ }^{99}$ the

v. Talley, 531 N.E.2d 1139, 1141 (Ill. App. Ct. 1988)) (noting also that the aggravated criminal sexual assault statute "does not specify a mental state" and therefore creates a general intent crime, and, "as such, the requisite mental state ordinarily follows the prohibited conduct").

95. See People v. Osband, 919 P.2d 640,681 (Cal. 1996) (defining rape as a general intent crime, and noting that "[w] $[w e n$ a person intentionally does that which the law declares to be a crime, he is acting with general criminal intent, even though he may not know that his act or conduct is unlawful") (emphasis added); The Queen v. Bernard [1988] 2 S.C.R. 833, 883 (Wilson, J.) (observing that sexual assault is a general intent crime, requiring no "intent or purpose beyond the intentional application of force") (emphasis added).

96. Commonwealth v. Grant, 464 N.E.2d 33, 35 (Mass. 1984).

97. See, e.g., State v. Lopez, 892 P.2d 898, 900-01 (Idaho Ct. App. 1995) (intoxication); State v. Hart, 477 N.W.2d 732, 736 (Minn. Ct. App. 1992) (intoxication); State v. Campos, 921 P.2d 1266, 1274-79 (N.M. 1996) (intoxication); State v. Daughtry, 459 S.E.2d 747, 761 (N.C. 1995) (diminished capacity); Boyd v. State, 572 P.2d 276, 278-79 (Okla. Crim. App. 1977) (intoxication); The Queen v. Bernard [1988] 2 S.C.R. 833 (intoxication).

98. See, e.g., People v. Corbiere, 559 N.W.2d 666, 668-69 (Mich. Ct. App. 1996); State v. Walden, 841 P.2d 81, 82-84 (Wash. Ct. App. 1992).

99. See, e.g., People v. Osband, 919 P.2d 640, 681 (Cal. 1996); People v. Bock, 611 N.E.2d 1173, 1186-88 (Ill. App. Ct. 1993); State v. Lamphere, 348 N.W.2d 212, 217 (Iowa 1984); State v. Plunkett, 934 P.2d 113, 117-19 (Kan. 1997); State v. Cantrell, 673 P.2d 1147, 1152-54 (Kan. 1983); Commonwealth v. Grant, 464 N.E.2d 33, 36-37 (Mass. 1984); Commonwealth v. Lefkowitz, 481 N.E.2d 227, 22932 (Mass. App. Ct. 1985); People v. Brown, 495 N.W.2d 812, 813 (Mich. Ct. App. 1992); State v. Hart, 477 N.W.2d 732, 735-36 (Minn. Ct. App. 1992); State v. Koperski, 578 N.W.2d 837, 847 (Neb. 1998); State v. Brown, 899 P.2d 34, 35 (Wash. Ct. App. 1995). Cf. Bryan v. State, 745 P.2d 905, 908-09 (Wyo. 1987) (rejecting defendant's argument that his guilty plea should be set aside because 
admissibility of the defendant's prior crimes, ${ }^{100}$ or the sufficiency of the prosecution's evidence of force ${ }^{101}$ or mens rea vis-a-vis nonconsent. ${ }^{102}$ And they are resolved on that basis, without further elucidation of the mens rea requirement as it applies to force.

\section{Strict Liability}

Finally, some courts seem to read the legislature's failure to include mens rea language in their rape statutes to imply that no state of mind requirement attaches to the element of force, thereby making force a matter of strict liability. As a practical matter, however, it is difficult to distinguish some of these opinions from those described in the prior section that treat rape as a general intent crime.

In State $v$. Neumann, for example, the Wisconsin Court of Appeals held that "no particular intent is required" to support a conviction for sexual intercourse "without consent, by use or threat of force or violence."103 After noting the absence of any mens rea requirement in the statute and examining its legislative history, the court concluded that "the legislature intentionally omitted any intent requirement" from the crime. ${ }^{104}$

Likewise, in State $v$. Reed, the Maine Supreme Court noted that the crime of forcible rape was "defined without reference to the actor's state of mind," concluding that "[t] $\mathrm{the}$ legislature ... clearly indicated that rape compelled by force or threat requires no culpable state of mind."105 But the court went on to remark that "one person cannot accidentally or innocently compel another to submit to

the trial judge failed to inform him that sexual assault was a specific intent crime).

100. See, e.g., State v. Crawford, 672 So. 2d 197, 209-11 (La. Ct. App. 1996).

101. See, e.g., Stokes v. State, 648 So. $2 d$ 1179, 1181-82 (Ala. Crim. App. 1994).

102. See, e.g., State v. Smith, 554 A.2d 713, 715-18 (Conn. 1989).

103. 508 N.W.2d 54, 62 (Wis. Ct. App. 1993).

104. Id. at $62-63$ (refusing to allow the defendant to raise an intoxication defense).

105. 479 A.2d 1291, 1296 (Me. 1984). 
sexual intercourse,"106 thereby suggesting that its view is more in line with the courts that consider rape a general intent crime. ${ }^{107}$ In any event, the mens rea issue was not significant to the outcome of the case, as the opinion focused on the trial judge's refusal to instruct the jury that it must find that the defendant "intentionally or knowingly used physical force against the complainant, knowing that she did not consent," and the court disposed of the case by upholding the jury instructions without inquiring into the nature of the defendant's mens rea vis-a-vis force. ${ }^{108}$

Finally, in Tobias $v$. State, the Indiana Supreme Court indicated not only that the defendant's mens rea with respect to force is not a significant factor in a rape prosecution, but also that the sole focus is on the victim's perception of the situation. ${ }^{109}$ Despite the fact that the Indiana rape statute requires proof that a defendant "knowingly or intentionally has sexual intercourse with a member of the opposite sex when: (1) the other person is compelled by force or imminent threat of force," $" 110$ the court explained:

[I]t is the victim's perspective, not the assailant's, from which the presence or absence of forceful compulsion is to be determined. This is a subjective test that looks to the victim's perception of the circumstances surrounding the incident in question. The issue is thus whether the victim perceived the aggressor's force or imminent threat of force

106. Id. But cf. State v. Pierce, 438 A.2d 247, 251-52 (Me. 1981) (using similar language when interpreting a prior version of the statute, in support of the conclusion that the prosecution need not prove a "specific intent to induce submission by means of a threat") (emphasis added).

107. See supra note 93 and accompanying text; see also Coler v. State, 418 So. 2d 238, 239 (Fla. 1982) (noting that "[s]tate of mind is not a material fact in a sexual battery charge, nor is intent an issue," but citing in support Askew v. State, 118 So. 2d 219, 222 (Fla. 1960), which treated sexual battery as a general intent crime and held that "no specific intent is requisite other than that evidenced by the doing of the acts constituting the offense").

108. Reed, 479 A.2d at 1295 .

109. 666 N.E.2d 68 (Ind. 1996).

110. Ind. Code Ann. $\$ 35-42-4-1$ (West Supp. 2000) (emphasis added). 
as compelling her compliance. ${ }^{111}$

But the court thought that the case involved an unquestionable use of force and therefore quickly disposed of the defendant's challenge to the sufficiency of the evidence of force, without adverting further to the mens rea requirement. ${ }^{112}$

Although some courts have therefore suggested that the element of force is a matter of strict liability, at times their reasoning is indistinguishable from that found in cases which treat rape as a general intent crime. Moreover, the references to mens rea in these opinions tend to be brief and offhand and to have no real bearing on the outcome of the case. These decisions are no different, therefore, from those described above in the previous sections, which while acknowledging the question of mens rea and force, discuss it only in passing. The one case that addresses the subject at any level of detail is described in the following section.

\section{People v. Evans}

In People v. Evans, perhaps the most well-known of the judicial opinions to discuss questions of mens rea as applied to the element of force, the trial court suggested that rape convictions require proof that the defendant intended to use force. ${ }^{113}$ The defendant in Evans pretended

111. Tobias, 666 N.E.2d at 72. But cf. People v. Witte, 449 N.E.2d 966, 971 n.2 (III. App. Ct. 1983) (making a similar observation but then holding that rape is a general intent crime, rather than a matter of strict liability).

112. See Tobias, 666 N.E.2d at 72 (reasoning that the victim was a sixteenyear-old girl, who was "clandestinely participating in an escapade of overnight camping, drinking, and sex with her boyfriend after deceiving her parents as to her whereabouts [and] was suddenly caught... by two adult men-one of whom was the defendant, age 58-representing and asserting the enforcement authority of the campground," who took her to a "remote, locked office" and "performed sexual intercourse on her ... after demanding her compliance; physically forcing himself upon her; and ignoring her lack of consent, verbal resistance, and requests for him to stop").

113. 379 N.Y.S.2d 912 (Sup. Ct. 1975), affd mem., 390 N.Y.S.2d 768 (App. Div. 1976). 
to be a psychologist interested in interviewing the victim for a magazine article. In addition to engaging in a variety of deceptive behaviors, he "took steps to cause doubt and fear to arise in [the victim's] mind" by saying: "Look where you are. You are in the apartment of a strange man. How do you know that I am really who I say I am? How do you know that I am really a psychologist?. . . I could kill you. I could rape you. I could hurt you physically."114 In finding insufficient evidence of the "forcible compulsion" required by New York's rape statute, the court observed that the defendant's comment that he "could" kill or rape the victim was "susceptible to two possible and diverse interpretations":

The first would be in essence that-you had better do what I say, for you are helpless and I have the power to use ultimate force should you resist. That clearly would be a threat which would induce fear and overcome resistance. The second possible meaning of those words is, in effect, that-you are a foolish girl. You are in the apartment of a strange man. You put yourself in the hands of a stranger, and you are vulnerable and defenseless. The possibility would exist of physical harm to you were you being confronted by someone other than the person who uttered this statement. ${ }^{115}$

Although the court acknowledged that it was "entirely possible" the victim interpreted the defendant's words as a threat, and that that interpretation was a reasonable one, the court concluded that "the controlling state of mind must be that of the speaker":

[T]his being a criminal trial, it is basic that the criminal intent of the defendant must be shown beyond a reasonable doubt. It is his intent when he acts, his intent when he speaks, which must therefore be controlling. And so, if he utters words which are taken as a threat by the person who hears them, but are not intended as a threat by the person

114. Id. at 917.

115. Id. at 920. 
who utters them, there would be no basis for finding the necessary criminal intent to establish culpability under the law. ${ }^{116}$

Picking up on the clear implication of the phrase italicized above, the New York Court of Appeals subsequently held in People $v$. Williams that "intent is implicitly an element" of the crime of rape even though the rape statute is "silent on the subject."117 But the court went on to align itself with those jurisdictions that treat rape as a general intent crime. "The intent required," the court continued, "is the intent to perform the prohibited act-i.e., the intent to forcibly compel another to engage in intercourse"118_language reminiscent of that appearing in some of the cases adopting the view that rape is a general intent crime. ${ }^{119}$ Moreover, the court rejected the defendants' claim that the jury should have been instructed that intent is an element of the crime and that a mistaken belief in consent could negate the requisite mens rea. Noting that the trial judge had instructed the jury that the crime required proof of lack of consent caused by forcible compulsion, the court explained that "it is unnecessary to forcibly compel another to engage in sexual acts unless that person is an unwilling participant."120 The court therefore concluded that the jury's finding that the defendants used physical compulsion to coerce the victim "necessarily" constituted a finding that they "believed the victim did not consent to the sexual activity."121 After Williams, therefore, New York seems to be a jurisdiction that considers rape a

116. Id. at 920-21 (emphasis added); see also Chavez v. State, 601 P.2d 166, 172 (Wyo. 1979) (observing that "[i]t is not possible to structure the criminal intent of the defendant out of the subjective attitudes of the alleged victim"; rather, the "general intent ... must exist in the mind of the perpetrator").

117. 614 N.E.2d 730, 736 (N.Y. 1993).

118. Id.

119. See supra notes $91-92$ and accompanying text.

120. Williams, 614 N.E.2d at 736.

121. Id. at 737; see also People v. Fenton, 563 N.Y.S.2d 522, 523 (App. Div. 1990) (observing, without citing Evans, that "[w]hile intent is clearly an element of rape in the first degree, we find that the element of intent is implicit in the element of forcible compulsion, on which the jury was properly instructed"). 
general intent crime, and the arena of debate has shifted from the question of mens rea vis-a-vis force addressed in Evans to the question of mens rea vis-a-vis consent. Thus, Evans turns out to be only a short-lived exception to the courts' general tendency to completely ignore the question of mens rea as it applies to the force requirement or, at best, to mention the issue in passing before resolving the case on other grounds. The implications of this pattern for the criminal law's insistence on requiring proof of both force and lack of consent in order to support a rape conviction are discussed in the following section.

\section{THE IMPLICATIONS}

The relative lack of attention given to the question of mens rea and force-and its insignificance to the outcome of the case in the rare opinion where it has been discussed-is not due to inattentiveness on the part of legislators, sloppy reasoning on the part of judges, or unimaginative lawyering on the part of defense counsel. Rather, the reason the issue has attracted so little attention is that the force and nonconsent elements of rape overlap with one another, making a mens rea requirement with respect to force redundant where the prosecution can prove lack of consent and its accompanying mens rea.

To be sure, it would seem pedestrian for a court to address separately the issue of mens rea in a case involving an obvious show of force-force that even "a schoolboy might recognize."122 In such circumstances, the defendant's use of force itself clearly demonstrates that he was acting with a culpable state of mind. Thus, for example, a defendant who beats his victim into submission or expressly threatens her with a weapon is obviously using force knowingly, if not purposefully. ${ }^{123}$ Faced with those facts, it makes sense for a court to reason that the

122. Estrich, supra note 4, at 66 .

123. See id. at $99-100$ (observing that, if proof of actual force is required to support a rape conviction, "the question of intent [does] not arise, since the use of such force [is] unlikely to be accidental"). 
defendant could not be "accidentally or innocently" using force, and therefore that proof of the actus reus-the use of force-"necessarily implies an intent or knowledge."124

At least as a theoretical matter, however, we can envision cases where the nature of the defendant's state of mind concerning force would be a debatable issue. One obvious example is Evans, where the trial court found the meaning of the defendant's comments about killing and raping the victim to be ambiguous. In addition, the defendant's mens rea vis-a-vis the force requirement could have been a controversial question in some of the other cases described above in Part II. Consider a case where the defendant has a weapon or a large dog in the room at the time in question, but it is unclear whether the defendant is purposefully using it to create fear or is oblivious of its presence and likely impact on the victim. ${ }^{125}$ The facts of Rusk provide another illustration. Was the defendant's act of "lightly" choking the victim intended to be "actual force" (as the majority in the Court of Appeals concluded ${ }^{126}$ ) or a "heavy caress" (as the Court of Special Appeals found ${ }^{127}$ )? When the defendant in State $v$. Weisberg "told" the victim to "lie down on his bed," and then, when she said she did not want to, responded, "go ahead and lay on the bed

124. For a description of opinions adopting this line of reasoning, see supra notes 93-94 and accompanying text.

125. For illustrations of such cases, see Reynolds v. State, 664 P.2d 621, 622, 630 n.3 (Alaska Ct. App. 1983) (the defendant carried the victim into his bedroom, where the victim saw a handgun on a chair; the trial judge found that the defendant "should have known that it would intimidate" the victim, even though he "never touched or even mentioned the handgun" and did not "intentionally rel[y] on the gun to intimidate her"); State v. Foster, 631 S.W.2d 672, 673, 674 (Mo. Ct. App. 1982) (the defendant had mentioned to the victim earlier that day that his two Doberman pinschers would "attack at his command," and the court concluded that she was "under the constant threat that defendant would command the dogs to attack her").

126. State v. Rusk, 424 A.2d 720, 728 (Md. 1981).

127. Rusk v. State, 406 A.2d 624, 628 (Md. Ct. Spec. App 1979), rev'd, 424 A.2d 720 (Md. 1981); see also Estrich, supra note 4, at 64 (observing that either the defendant or the victim in Rusk could have been lying or, alternatively, "neither was lying [and] 'light choking' to her was nothing more than a 'heavy caress' to him"); Dressler, supra note 10, at 420 (commenting that "one person's light choke is another person's inartful caress"). 
anyway," did he speak in a menacing or a cajoling tone of voice? ${ }^{128}$ In cases involving more than one defendant, where one of them made threats or exerted force, it may not be clear whether the others were aware of and took advantage of that show of force. ${ }^{129}$ Similarly, where the victim fears the defendant because of a past history of abuse, it may be open to question whether the defendant is trying to capitalize on her fear or completely unfamiliar with her history. ${ }^{130}$

Although the defendant's state of mind regarding force may be debatable in each of these instances, Evans is the only one of the cases on which these hypotheticals are based that actually turned on the court's analysis of that issue. Had the question of mens rea vis-a-vis force been raised in any of these other settings, the outcome of the case would have depended on the particular mens rea

128. 829 P.2d 252, 254 (Wash. Ct. App. 1992) (finding insufficient evidence of the "forcible compulsion" required to support a rape conviction because there was "absolutely no evidence indicating either that Weisberg suggested or threatened harm to [the victim] if she did not comply or that he used any physical force to obtain compliance").

129. For illustrations of such cases, see People v. Brown, 495 N.W.2d 812, 813 (Mich. Ct. App. 1992) (the defendant found the victim sitting alone in a bedroom, naked and crying, and claimed that he did not know she had been kidnapped and raped by other men in the house); State v. Miller, 466 S.E.2d 507, 510 (W. Va. 1995) (the defendant's brother, who was also the stepfather of the thirteen-yearold victim, told the defendant that the victim "wanted to do it," but there was no discussion between the defendant and the victim; the court found sufficient evidence that the victim feared that her stepfather would beat her if she refused and that the defendant was aware of the forcible compulsion exercised by his brother, despite the defendant's allegation that he and his brother "did not speak and had a poor relationship"); Chavez v. State, 601 P.2d 166, 168 (Wyo. 1979) (the defendant's companion, who was obviously drunk, "bragged about his gun" to the victim and said "he enjoyed shooting it," but it was not clear that the defendant was present during this conversation).

130. For illustrations of such cases, see State v. Zamudio, 645 P.2d 593, 594-95 (Or. Ct. App. 1982) (the defendant's wife told the victim a month earlier that the defendant had beaten and injured her; in addition, the victim had herself been beaten by her husband, and she told the defendant that she was "real nervous about men"); Marcia Baron, "I Thought She Consented," 11 Phil. Issues (forthcoming 2001) (hypothesizing a situation where a "survivor of chronic sexual abuse ... is so accustomed to refusal being pointless (and more likely dangerous, as well), so accustomed to accommodating the men who abused her, that she is unable to express refusal ... if the initiator is at all pushy"). 
requirement adopted in that jurisdiction and the jury's assessment of whether that requirement had been met. Some jurors might reasonably have thought, for example, that the defendant purposefully used certain words or facial expressions, or purposefully relied on the presence of a weapon or dog, to create fear in the victim's mind, and thus as an implicit threat. Others might conclude only that he knew-or should have known-that those factors were likely to have such an effect on the victim. Still others might believe that he lacked any culpable mens rea whatsoever, even though the victim thought he was using or threatening force.

If the applicable state of mind requirement was negligence - so that the issue became whether a reasonable person would have thought the defendant was using force-the question would arise as to whose perspective controls. Given " $t]$ he reality of our existence... that it takes less force to overcome most women than most men," "[t]he question of whose definition of 'force' should apply, of whose understanding should govern, is critical."131 That issue is particularly critical today given the "gender gap"132_-perhaps more accurately termed the "gender chasm"-in our "perceptions of when sex [is] forced." As one commentator explained:

Because both men and women are socialized to accept coercive sexuality as the norm in sexual behavior, men often see extreme forms of this aggressive behavior as seduction, rather than rape. A great many incidents women consider rape are, in effect, considered "normal" by both male perpetrators and the male-dominated legal system.... Thus, what is "normal" according to male social norms and "reasonable" according to male communication patterns and

131. Estrich, supra note 4 , at 22,60 .

132. Robin D. Weiner, Note, Shifting the Communication Burden: A Meaningful Consent Standard in Rape, 6 Harv. Women's L.J. 143, 147 (1983).

133. Robert T. Michael et al., Sex in America: A Definitive Survey 221, 223, 227 (1994) (describing survey results indicating that twenty-two percent of women reported having been "forced to do something sexually at some time," whereas only three percent of men admitted ever "having forced a woman"). 
expectations does not accord with what women believe to be reasonable....

. . A reasonable woman... may perceive certain behavior as indicating that the man plans to have sex with her whether she consents or not, although the man may not have meant to communicate such an intent.

. . . A woman may believe she has communicated her unwillingness to have sex-and other women would agree, thus making it a "reasonable" female expression. Her male partner might still believe she is willing-and other men would agree with his interpretation, thus making it a "reasonable" male interpretation. The woman, who believes she has conveyed her lack of consent, may interpret the man's persistence as an indication that he does not care if she objects and plans to have sex despite her lack of consent. ${ }^{134}$

Although the Evans court thought that the man's state of mind ought to control in cases where the gender gap is at work-because in "a criminal trial, it is basic that the criminal intent of the defendant must be shown beyond a reasonable doubt," and therefore "[i]t is his intent when he acts, his intent when he speaks, which must... be controlling ${ }^{\prime 135}$ _that view is not without its critics. For example, Catharine MacKinnon has pointed out that it is

134. Weiner, supra note 132 , at $147-49$; see also Schulhofer, supra note 3 , at 256 (observing that "many men see nothing improper about continuing to press forward with physical advances in spite of a date's passivity or even direct signs of her unwillingness," and "even if she is emphatic, her effort to communicate may not be sufficient to bridge the gender gap"); Henderson, supra note 4, at 159 (noting that “[m]en just don't see the violence”); McGregor, supra note 8, at 189 (commenting that "notions of force, violence, and threat are elastic-in other words, what women view as threatening or forceful, men may not").

135. 379 N.Y.S.2d 912, 921 (Sup. Ct. 1975), affd mem., 490 N.Y.S.2d 768 (App. Div. 1976); see also Schulhofer, supra note 3, at 257 (observing that "[e]mphasis on the defendant's perspective is the traditional starting point in a criminal case, because the question to be decided is not just whether a victim has been hurt but whether the defendant deserves to suffer criminal punishment for causing the injury"). 
problematic to define the crime of rape "from the male point of view" given that rape is "only an injury from the women's point of view": "the injury of rape lies in the meaning of the act to its victim, but the standard for its criminality lies in the meaning of the act to the assailant." ${ }^{36}$ Likewise, another commentator has criticized the criminal law's focus on the man's point of view as "a distortion of the reality of rape." 137

However one comes out on the question of whose perspective ought to control, the fact is that this subject has not received much attention from the courts because the defendant's mens rea with respect to force has not been an issue of any practical significance-even in the type of cases described above where, as an abstract matter, it might have been debatable. Instead of analyzing whether the defendant purposely or knowingly used force, or should have known that he was using force, the courts have disposed of such cases by evaluating the sufficiency of the evidence offered to prove either the actus reus of force or the defendant's mens rea vis-a-vis nonconsent. The absence of any real discussion of mens rea with respect to force points up the redundancy of the force requirement, once absence of consent has been proven.

Although numerous courts have accepted the notion that proof of force demonstrates lack of consent, ${ }^{138}$ a few notable court opinions have refused to accept the converse proposition and therefore have reversed rape convictions after concluding that the element of nonconsent was

136. Mackinnon, supra note 3 , at 180 .

137. Patricia Hughes, From a Woman's Point of View, 42 U. New Brunswick L.J. 341, 343 (1993).

138. See, e.g., Ex parte Gordon, 706 So. 2d 1160, 1163 (Ala. 1997) (observing that "[f]orcible compulsion is conclusive presumptive evidence of lack of consent") (emphasis deleted); State v. Rivera, 638 A.2d 34, 35 (Conn. 1994) (commenting that " $[w]$ here use of force or a threat of force is proven beyond a reasonable doubt, lack of consent is implicit... [b]ecause the use of force or a threat of force is essentially the converse of consent") (quoting the appellate court's opinion); People v. Jansson, 323 N.W.2d 508, 513 (Mich. Ct. App. 1982) (noting that "to prove force or coercion ... is to establish that the victim did not consent"); see also McGregor, supra note 8, at 184 ("it would seem logical to assume that if force is present it is because consent is absent"). 
proven, but not the element of force. One such case was State v. Alston, where the North Carolina Supreme Court found sufficient evidence that the victim had "expressly and unequivocally" communicated her lack of consent, but "no substantial evidence of either actual or constructive force."139 Another was Commonwealth v. Berkowitz, where the Pennsylvania Supreme Court likewise did not question the evidence of nonconsent-in the court's words, the victim "stated 'no' throughout the encounter" with the defendant-but found insufficient evidence of the "forcible compulsion" required by the state's rape statute. ${ }^{140}$ But there are few such decisions, and they have proven quite controversial.

139. 312 S.E. 2 d $470,475,476$ (N.C. 1984). The court reached this conclusion despite evidence that the defendant had previously battered the victim and, shortly before intercourse, had "threatened to 'fix' her face." Id. at 472 . These facts prompted one commentator to observe that the Alston court defined the concept of force "strictly in schoolboy terms," using "the most traditional male notion of a fight." Estrich, supra note 4, at 62 . The defendant "did not beat his victim-at least not with his fists"-because "[h]e didn't have to," given that "[s]he had been beaten, physically and emotionally, long before." Id.; see also Schulhofer, supra note 3 , at 76 (criticizing the Alston court's approach as "artificial because it focuses narrowly, in snapshot fashion, on specific comments and gestures at the time of a rape incident... without considering the broader context"). The North Carolina Supreme Court itself subsequently described Alston as "unique" and "peculiar," State v. Brown, 420 S.E.2d 147, 151, 150 (N.C. 1992), leading another commentator to conclude that the court "has virtually repudiated its decision in Alston." Dressler, supra note 10, at 421.

140. $641 \mathrm{~A} .2 \mathrm{~d} \mathrm{1161}, 1164$ (Pa. 1994) (reversing the defendant's rape conviction, though affirming his conviction on the lesser charge of indecent assault, defined as "indecent contact ... . without . . . consent"). The court explained that, although the evidence showed that the defendant "pushed [the victim] onto the bed," she described the "push" as "kind of in the middle" between "a romantic kind of thing" and "a fast shove." Id. at 1163, 1164. The court likewise dismissed the fact that the defendant locked the door to his dorm room by noting that "the door could be unlocked easily from the inside, ... she was aware of this fact, but ... she never attempted to go to the door or unlock it." Id. at 1164. And the court thus concluded that "the weight of his body on top of her was the only force applied." Id. But cf. Susan Estrich, Rape: A Question of Force, USA Today, Aug. 11, 1994, at $13 \mathrm{~A}$ (commenting that "[t]he body of a man who's 50 pounds heavier than you, stronger than you, a more experienced fighter than you, ignoring your words, determined to have sex, can certainly feel like force from the bottom"). In response to the court's decision in Berkowitz, the Pennsylvania legislature created the crime of sexual assault, a lesser offense than rape, which punishes intercourse without consent. See supra notes $9 \& 29$. 
Some commentators have criticized opinions like Alston and Berkowitz unequivocally, arguing that to say that intercourse was nonconsensual, but not forcible, "creates a paradox."141 It is a "clear contradiction," Susan Estrich explains, to conclude that "the woman was not forced to engage in sex (as proven by her failure to resist), but the sex she engaged in was against her will."142

Other commentators seem sympathetic at least with the sentiment underlying Alston and Berkowitz, if not their specific results. Although many of them endorse the creation of a lesser offense for nonforcible, nonconsensual intercourse, they believe that forcible, nonconsensual intercourse is a more culpable act. ${ }^{143}$ Advocating such a two-tiered approach, Donald Dripps offers the following explanation:

Physical violence in general does far more harm to the victim's welfare than an unwanted sex act. Physical violence in general expresses a more complete indifference, or a more intense hostility, to the victim's humanity. ... .

... [P]eople generally, male and female, would rather be subjected to unwanted sex than be shot, slashed, or beaten with a tire iron.... [W] hether measured by the welfare or by the dignity of the victim, as a general matter unwanted sex is not as bad as violence. I think it follows that those who press sexual advances in the face of refusal act less

141. Estrich, supra note 4, at 62.

142. Id.; see also Henderson, supra note 4, at 158 (commenting that "it should go without saying that if a woman does not want to engage in intercourse and is not consenting, the man has to force her into the act"). A few judges have likewise recognized this point. See, e.g., State v. Collins, 508 S.E.2d 390, 397 n.32 (Ga. 1998) (Hunstein, J., dissenting) (noting that "[f]rom the victim's perspective, where it is against her will to engage in sexual intercourse, the act occurs necessarily by force; from the perpetrator's perspective, where force must be used to engage in sexual intercourse, the act is necessarily against the will of the victim").

143. See, e.g., Schulhofer, supra note 3, at 105, 280; Dressler, supra note 10, at 423, 426; Dripps, supra note 2; McGregor, supra note 8, at 190. 
wickedly than those who shoot, or slash, or batter. ${ }^{144}$

Others have criticized Dripps' characterization, arguing that it "wildly misdescribes the experience of rape,"145 and ignores the fact that all nonconsensual sex creates an "injury to personal integrity"146 and "dehumanizes the victim" by violating the "autonomous right to control one's own body" in "an area that is central to one's identity and personhood." ${ }^{47}$ Robin West explains:

First, unwanted, undesired penetration of a woman who has expressed a refusal, by a man who then ignores her refusal, is a violent act. It is a physical intrusion of one's body, it causes pain, and if that intrusion ... is non-violence, I'm not sure I understand what violence is. Second, for the acts ... to be successful, ... there must be an implied threat that the man would use a very real weapon, namely, his fists.... [E]very sexual act in which sex happens after a woman has expressly refused it involves both the violence of the unwanted penetration and the threat of further violence should the woman refuse to cooperate. ${ }^{148}$

The commentators who endorse a two-tiered approach respond that treating forcible, nonconsensual intercourse and nonforcible, nonconsensual intercourse equivalently "trivializes the concept of forcible rape and the harm

144. Dripps, supra note 2 , at $1792,1800-01$.

145. Robin L. West, Legitimating the lllegitimate: A Comment on Beyond Rape, 93 Colum. L. Rev. 1442, 1448 (1993).

146. Estrich, supra note 4, at 103.

147. McGregor, supra note 8 , at 191 ; see also Jane E. Larson, "Women Understand So Little, They Call My Good Nature Deceit": A Feminist Rethinking of Seduction, 93 Colum. L. Rev. 374, 453 (1993) (arguing that "[i]nvoluntariness is harmful in and of itself because it destroys autonomy and choice").

148. Robin West, Men, Women and Rape, 63 Fordham L. Rev. 125, 150 (1994); see also Dorothy E. Roberts, Rape, Violence, and Women's Autonomy, 69 Chi.Kent L. Rev . 359, 373, 371 (1993) (observing that "[f]orced sexual penetration is itself a battery, resulting in physical and mental injuries," whereas "Dripps's scheme denies any violence at all in the act of unwanted penetration"); West, supra note 145, at 1448 (noting that "If]rom the victim's perspective, unwanted sexual penetration involves unwanted force, and unwanted force is violent"). 
experienced by victims of the most violent rapes."149 But it seems somewhat ironic to fault the suggestion that certain types of rape should be taken seriously on the ground that doing so "trivializes" the experience of other rape victims, when the history of the law of rape has been to trivialize the experience of rape victims generally. Moreover, the experience of even "nonviolent" rape is terrifying and causes substantial psychological harm. ${ }^{150}$ Thus, as Dorothy Roberts points out, creating distinctions between "seemingly nonviolent sexual coercion" and "sex accompanied by physical violence" tends to "obscure the common nature of both." 151 Although "there may well be a difference" between forcible and nonforcible nonconsensual intercourse, it is "not the difference between violent and non-violent rape," but rather "[i]t is the difference between lots of violence and not as much violence, or lots of force and not much force."152

Despite the commentators' disagreement about the appropriate level of punishment, many of them agree that

149. Dressler, supra note 10 , at 423 ; see also Donald Dripps, Men, Women and Rape, 63 Fordham L. Rev. 125, 162 (1994). Cf. Bryden, supra note 14, at 375 (maintaining that "lump[ing] together forcible and nonforcible offenders ... would create the possibility of excessive sentences for the nonforcible rapes").

150. See, e.g., Schulhofer, supra note 3, at 279 (explaining that "unwanted sex with an acquaintance tends to produce deep psychological harm, the victim may suffer a lasting inability to trust those close to her, and her emotional distress may persist as long as in the case of forcible rape by a stranger"); Roberts, supra note 148 , at 374 (observing that the "physical trauma and disregard of her personhood that [the victim of nonconsensual intercourse] experienced is a form of violence" that is no "less painful or degrading than if he had raised his fist"); West, supra note 148, at 151 ("At least if we are to believe the testimony of both rape victims and crisis center workers, rape victims are always terrified, and always terrified for their lives, and for a very simple reason: anyone who would so trivialize you as to impose non-consensual sex is also capable of killing you."). Cf. J.H. Bogart, Reconsidering Rape: Rethinking the Conceptual Foundations of Rape Law, 8 Can. J.L. \& Jurisprudence 159, 170 (1995) (pointing out that if the harm suffered by the victim were a critical measure of culpability, a defendant who raped "a victim of unusual resilience and strength with an unusually supportive network" would receive a lighter sentence).

151. Roberts, supra note 148 , at 381 ; see also West, supra note 148 , at 159 (arguing that lenient treatment of nonconsensual, nonforcible rape "truly trivializes the experience of the woman victimized during the event").

152. West, supra note 148 , at 163. 
nonforcible, nonconsensual intercourse is deserving of criminal sanction. As noted above, ${ }^{153}$ however, the courts have been hesitant to expressly endorse that viewpoint. But the fact that they actually decide rape cases without much analysis of defendants' mens rea vis-a-vis the force requirement confirms that, at least implicitly, they acknowledge that the issue of force is redundant and therefore moot once lack of consent has been established. In cases where courts are satisfied that the victim did not consent, and the defendant had a culpable mens rea vis-avis that lack of consent, they have generally affirmed rape convictions without paying much attention to questions of force or the defendant's mens rea vis-a-vis force. And rightly so. If the victim did not consent, and the defendant nevertheless proceeded to have intercourse with her, possessing the mens rea vis-a-vis her lack of consent required in that jurisdiction to support a rape conviction, he committed a culpable act that ought to be punished..$^{154}$

Acknowledging the primacy of nonconsent is also in line with the policies underlying the prohibition of rape. As the California Court of Appeal explained in People $v$. Cicero:

[T] he fundamental wrong at which the law of rape is aimed is not the application of physical force that causes physical harm. Rather, the law of rape primarily guards the integrity of a woman's will and the privacy of her sexuality

153. See supra notes $9-11$ and accompanying text.

154. In those jurisdictions that treat nonconsent as a matter of strict liability, see supra note 17 and accompanying text, it is arguable that a rape conviction ought not to be based solely on evidence that the victim did not consent to the intercourse, without some indication that the defendant either used force or had a culpable state of mind vis-a-vis her lack of consent. Absent a requirement of express consent, however, it seems unlikely that a jury would find absence of consent in a case involving evidence of neither force nor words or actions on the victim's part that would have signaled to the defendant that she was not consenting. Cf. Williams, supra note 15, at 15 (defending the House of Lords' decision in Director of Public Prosecutions v. Morgan, [1976] App. Cas. 182, which is described above in text accompanying notes $12-13$, by observing that "if anyone would have realised from what the woman said and did that she was not consenting, then [the jurors] are entitled to conclude that the defendant realised $\left.i t^{n}\right)$. 
from an act of intercourse undertaken without her consent. ${ }^{155}$

Therefore, the court concluded, "force' merely plays a supporting evidentiary role, as necessary only to insure an act of intercourse has been undertaken against a victim's will."156 In a similar vein, Patricia Falk has commentedsomewhat less charitably, but perhaps more realisticallythat the perception that a force requirement is needed in order to "supply external evidence of nonconsent" is probably based on "rampant, sexist distrust of rape victims." 157

Whether one takes a more or less charitable view of the motives underlying the criminal law's adoption of a force requirement, the elements of force and nonconsent are duplicative of one another. A woman who did not consent to intercourse was, by definition, forced, and one who was forced did not consent. By the same token, a defendant who knew (or should have known) that the victim did not consent also knew (or should have known)

155. 204 Cal. Rptr. 582, 590 (Ct. App. 1984); see also Rollin M. Perkins \& Ronald N. Boyce, Criminal Law 198, 210 (3d ed. 1982) (noting that the English common law definition of rape was "unlawful intercourse ... . without the consent of the woman"; the "reference to force [in Blackstone's definition of rape] was not found in the earlier definition given by Coke and its use has tended to cause confusion rather than to clarify the law"). For Blackstone's definition of rape, see supra text accompanying note 1 .

156. Cicero, 204 Cal. Rptr. at 590 (advocating that the law of rape require "only such force as is necessary reasonably to demonstrate that an act of intercourse has been undertaken without the victim's consent").

157. Falk, supra note 23, at 155; see also Estrich, supra note 4, at 58 (observing that "force has replaced consent or corroboration or unchastity as the primary doctrinal rubric for expressing... distrust" of rape victims). For evidence indicating that this distrust is misplaced, see People v. Barnes, 721 P.2d 110, 121 (Cal. 1986) (describing the impact of the criminal law's historic distrust of rape victims and concluding that "previous expectational disparities, which singled out the credibility of rape complainants as suspect, have no place in a modern system of jurisprudence"); State ex rel. M.T.S., 609 A.2d 1266, 1273 (N.J. 1992) (citing critics of "the stereotype that rape victims [are] inherently more untrustworthy than other victims of criminal attack"); Morrison Torrey, When Will We Be Believed? Rape Myths and the Idea of a Fair Trial in Rape Prosecutions, 24 U.C. Davis L. Rev. 1013, 1028 (1991) (criticizing the myth that rape victims are not credible, and noting that "there is no empirical data to prove that there are more false charges of rape than of any other violent crime"). 
that he was forcing her to submit. Therefore, proof of either lack of consent on the part of the victim or the use of force on the part of the defendant-plus the accompanying mens rea $^{158}$-ought to suffice to support a rape conviction. And the fact that courts routinely ignore questions of mens rea and force, in contravention of the general criminal law presumption that a mens rea requirement attaches to every material element of the crime, demonstrates that they too recognize, at least implicitly, that the traditional "conjunction of force and nonconsent"159 is "arbitrary,"160 "indefensible," 161 and "redundant."162

158. While I believe that those who advocate requiring a mens rea of negligence with respect to the element of nonconsent have the better argument, others disagree. See supra notes $12-17$ and accompanying text. But whatever mens rea a particular jurisdiction chooses to apply to the element of nonconsent ought to apply to the element of force as well, because essentially the same policy considerations underlie both decisions.

159. Dripps, supra note 2 , at 1792.

160. Id.

161. West, supra note 6 , at 233 .

162. MacKinnon, supra note 3 , at 172 . 
